\title{
On the Systematics and Biodiversity of the Opheliidae and Scalibregmatidae
}

\author{
Julio Parapar ${ }^{1, *(\mathbb{D}}$, Alejandro Martínez ${ }^{2} \mathbb{D}$ and Juan Moreira ${ }^{3}(\mathbb{D}$ \\ 1 Departamento de Bioloxía, Facultade de Ciencias, Universidade da Coruña, 15008 A Coruña, Spain \\ 2 Molecular Ecology Group (MEG), Water Research Institute (IRSA), National Research Council of Italy (CNR), \\ Largo Tonolli 5, 28922 Pallanza, Italy; alejandro.martinezgarcia@cnr.it \\ 3 Departamento de Biología (Zoología) \& Centro de Investigación en Biodiversidad y Cambio \\ Global (CIBC-UAM), Facultad de Ciencias, Universidad Autónoma de Madrid, 28049 Madrid, Spain; \\ juan.moreira@uam.es \\ * Correspondence: julio.parapar@udc.es
}

Citation: Parapar, J.; Martínez, A.; Moreira, J. On the Systematics and Biodiversity of the Opheliidae and Scalibregmatidae. Diversity 2021, 13, 87. https://doi.org/10.3390/ d13020087

Academic Editor: Luc Legal

Received: 30 December 2020

Accepted: 12 February 2021

Published: 18 February 2021

Publisher's Note: MDPI stays neutral with regard to jurisdictional claims in published maps and institutional affiliations.

\begin{abstract}
In this paper we review the systematics, diversity, and ecology of two related annelid families: Opheliidae Malmgren, 1867 and Scalibregmatidae Malmgren, 1867. Opheliids are depositfeeders and that are mainly found as burrowers in sandy sediments. Morphologically, opheliids are characterized by the smooth cuticle, as well as the presence of a conspicuous ventral groove, reduced parapodia, and a tubular-shaped structure often projecting from the posterior end. Scalibregmatids are also deposit-feeders, but compared to opheliids, they have a characteristic arenicoliform body, a T-shaped anterior end and a glandular, reticulated epidermis. For each family, we summarize the available information about the evolutionary relationships, taxonomic history, geographical distribution, ecological preferences and diversity of life strategies along with the techniques most commonly used for their study. By highlighting the main gaps in knowledge on each of these topics, this review ultimately aims at stimulating further research into members of these two families in the future.
\end{abstract}

Keywords: Opheliidae; Scalibregmatidae; diversity; taxonomy; anatomy; biology

\section{Introduction}

Opheliidae Malmgren, 1867 is a well-known family of annelids distributed throughout the world mostly in sandy sediments [1-3]. Most of the described five to six genera and ca. 160 species of opheliids include elongate, deposit-feeding burrowing worms, which are easily recognized by the smooth cuticle and the presence of a conspicuous ventral groove along at least the posterior half of the body (Figure 1). Opheliids usually have a conical to pointed prostomium that lacks lateral antennae, whereas their pygidium often develops a tubular-shaped prolongation that may bear cirri and marginal papillae. Although some species may reach $100 \mathrm{~mm}$ in length, most opheliids range between $5-70 \mathrm{~mm}$ and their trunk comprise about 30-60 segments [4].

The knowledge on opheliid taxonomy and systematics has been substantially improved in the last two decades, including the delineation of subfamilies and phylogenetic affinities [1]. However, further work is still needed in order to assess the validity of the genus Ammotrypanella McIntosh, 1879 and some species of Ophelia Savigny, 1822 and Ophelina Örsted, 1843, as well as the status of the many synonymies attributed to the presumably cosmopolitan Polyophthalmus pictus (Dujardin, 1839). The opheliid fauna of some geographic areas is well known (e.g., North Atlantic, California) whereas other regions remain clearly understudied and may potentially hold many undescribed species (e.g., Tropical Atlantic, Indo-Pacific and Australasia). The biology, ecology, and burrowing behavior of some species were studied in detail due to their ecological importance in the intertidal and shallow subtidal of sandy beaches at temperate and tropical latitudes (e.g., [5-10]). 
Some of these shallow water opheliids represent promising bioindicator species and have been even the target of experimental toxicological studies [11,12]. In contrast, we know virtually nothing on the biology of the opheliid species found at greater depths, despite their numerical importance in many macrofaunal assemblages in the deep-sea [13].

Traditionally, opheliid taxonomy has been based on conspicuous morphological characters, such as the number of branchiate chaetigers and different features associated to the anal tube. However, the branchiae and the anal tube are easily detached or damaged, leading to the wrong assessment of their absence or presence during species descriptions and identification and producing too much taxonomic confusion in the past (e.g., $[1,2,14,15])$. On the other hand, recent studies based on scanning electron microscopy (SEM) have revealed that the extended presence of lateral organs as well as a variety of nuchal organs features [1,15] may represent reliable taxonomic characters in those animals with simple bodies, reduced parapodia, and apparently similar simple chaetae. The internal anatomy of several opheliids has been studied in detail during the first half of the 20th century $[16,17]$, when much attention was paid, for instance, to the structure of the sensory organs (e.g., [18,19]) and the arrangement of the body musculature (e.g., [20,21]). Methodological approaches such as the use of microcomputed X-ray tomography (Micro-CT) may update some of the results from these studies and provide further morphological support for the described genera (e.g., features of the digestive tract) by revealing new phylogenetically informative characters.

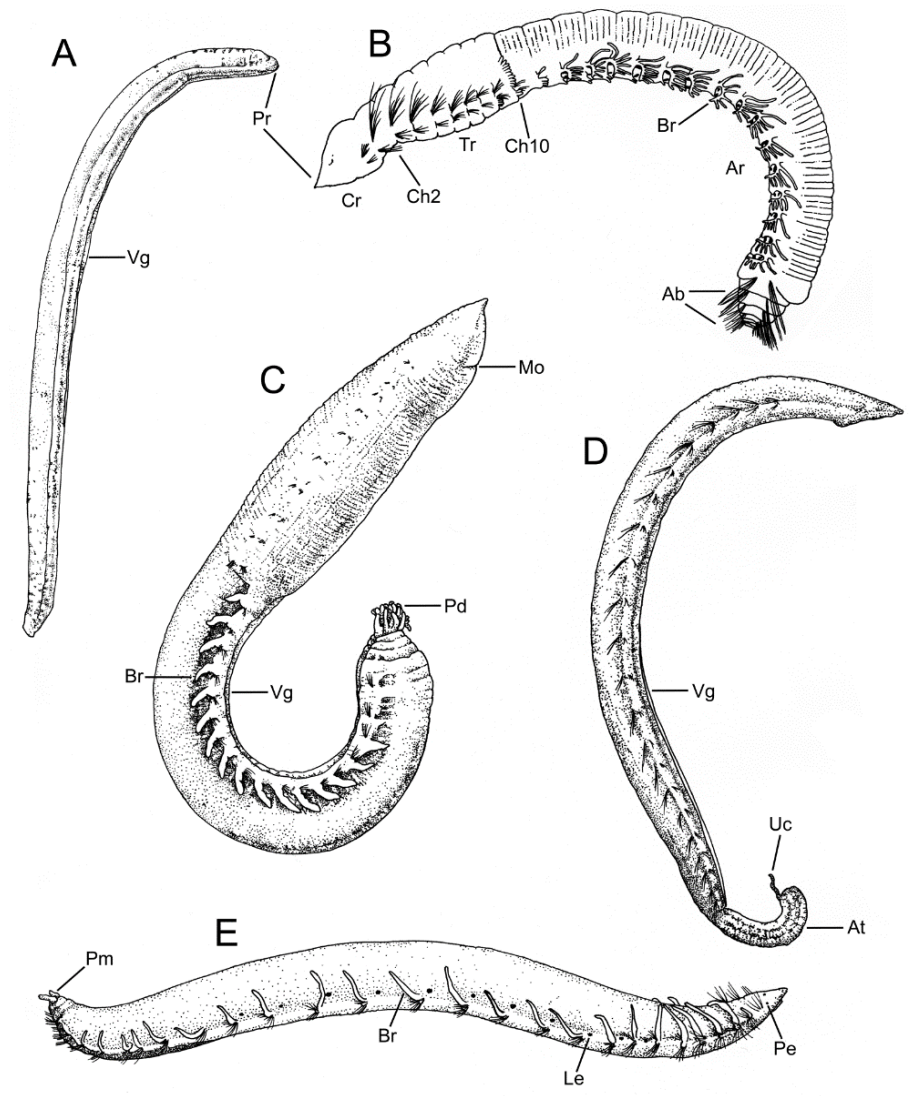

Figure 1. Stylized drawings of opheliids of the subfamily Opheliinae $(\mathbf{B}, \mathbf{C})$ and Ophelininae $(\mathbf{A}, \mathbf{D}, \mathbf{E})$. (A) Polyophthalmus pictus in latero-ventral view; (B) Thoracophelia japonica in lateral view (chaetiger numbers mark limit between body regions); (C) Ophelia bicornis in lateral view; (D) Ophelina abranchiata in lateral view; (E) Armandia cirrhosa in lateral view. (A,C-E) redrawn after Parapar [4]; (B) modified after Misaka and Sato [22]. Abbreviations: Ab-abranchiate chaetigers; Ar-abdominal region; At—anal tube; $\mathrm{Br}$ - branchia; $\mathrm{Ch}$-chaetiger; $\mathrm{Cr}$-cephalic region; Le-lateral eye; Mo-mouth; $\mathrm{Pd}$-pygidium dorsal papillae; $\mathrm{Pe}$ - prostomial subdermal eye; $\mathrm{Pm}$ - pygidium marginal papillae; $\mathrm{Pr}$ - prostomium; $\mathrm{Tr}$ - thoracic region; Uc—unpaired anal cirrus; $\mathrm{Vg}$ - ventral groove. 
Scalibregmatidae is a worldwide distributed family of sedentary annelids currently including ca. 70 described species classified in 14 genera (see below) [3,23]. Most species are subsurface deposit-feeders and prefer muddy bottoms at considerable depths or in high latitudes. Typically, they range between $5-70 \mathrm{~mm}$ in body length, exhibiting a vividly red pigmentation and a relatively simple external morphology [24]. Traditionally, the body shape has been categorized either as arenicoliform, i.e., more or less elongated and tapering towards the posterior end, or as maggotlike, i.e., relatively short and stout [25]. The epidermis is thick and glandular, and each trunk segment is often divided in one to six annulated rows of elevated pads that give the body a characteristic tesselate appearance. The prostomium is usually small and forms a pair of lateral or frontal prostomial appendages, which give the anterior end a characteristic T-shaped appearance. The pygidium is typically simple and possesses a variable number of cirri. However, there are several exceptions to this body plan within morphologically divergent species classified in the genera Axiokebuita, Speleobregma, and Scalibregmella [26,27].

Scalibregmatids have been known for a relatively long period of time, and indeed, quite extensive monographs on the group were already published during the 19th and the early 20th centuries [28-30]. However, despite this early interest, the phylogenetic position of the family as well as the relationships amongst its genera remain poorly understood. This is despite the several taxonomic revisions that the family has undergone during the last few decades, notably involving the rearrangement of several genera $[25,31,32]$ and the transference of the genus Travisia to the newly erected family Travisiidae [33]. While most Scalibregmatidae has been described from the Northern Atlantic [34,35], the family is unusually diverse in the Antarctic Ocean, from where 16 species have been described so far $[31,36,37]$. Most of those Northern Atlantic and Antarctic species have been recorded from muddy bottoms, where they might become very abundant and even locally dominate the benthic community. Records of scalibregmatids in lower latitudes are scarcer but often come from a wider range of environments, including sandy bottoms, Posidonia and Zostera seagrass meadows [38], corals and sponges [25,39], mussel beds [40], or even marine and anchialine cave systems [26].

Despite that the internal anatomy of Scalibregmatidae has long been known [28,41], no recent studies have revisited these early anatomical studies using modern imaging techniques. This has hampered our understanding of both the phylogenetic position of the family as well as its internal relationships insofar as the homology of many scalibregmatid characters in relation to other annelids [36,42,43], as well as the character evolution within the group remain obscure. Consequently, both the family Scalibregmatidae as well as many of its genera are diagnosed without any synapomorphies [24,44], but rather based on combinations of few external morphological characters $[23,24,30,44]$ whose inter- and intraspecific variability remain, in general, poorly understood. The fact that many scalibregmatids have been described from limited or fragmented material has aggravate this situation $[27,40]$, also because many traditional characters vary substantially across life stages of the same species [26,36]. This situation can be improved integrating different microscopical techniques in future taxonomic descriptions. This approach has already been followed by recent studies, which have successfully included previously overlooked characters, such as arrangement of ciliary bands, glands, or patterns of the epidermal ornamentation, in the diagnoses of several new species $[26,36]$.

In this contribution, an updated revision of the current biodiversity knowledge of the families Opheliidae and Scalibregmatidae is provided, and an update in taxonomy, classification, and systematics of the members of both taxa, highlighting where major gaps in knowledge lie and where future efforts could be made.

\section{Methods}

Published literature on opheliids and scalibregmatids was reviewed thoroughly aiming for information on diversity, ecology, and distribution. The World Register of Marine Species [3] database was mostly used as the basis for systematic arrangement, syn- 
onymies and valid genera and species, as well as Blake and Maciolek [1] for Opheliidae and Blake [23] for Scalibregmatidae. Furthermore, brief accounts on systematics and general morphology of these families are also provided as well as tables with valid nominal species including type locality, depth (from original description) and marine realms (sensu [45]) (Tables A1 and A2 in Appendix A).

\section{Results}

3.1. Opheliidae Malmgren, 1867

\subsubsection{Systematics}

Until recently, the Opheliidae comprised three subfamilies: Opheliinae HartmanSchröder, 1971, Ophelininae Hartman-Schröder, 1971 and Travisiinae Hartmann-Schröder, 1971. The latter only included the genus Travisia Johnston, 1840 that differed from other opheliids in having a grublike appearance and a papillated cuticle. Indeed, recent molecular phylogenetic analyses have demonstrated the monophyly of opheliids if the Travisiinae are excluded [46], subsequently motivating the establishment of Travisiinae as a family by Blake and Maciolek [33]. In fact, this possibility had been already proposed by Blake [47], Bleidorn et al. [48] and Hall et al. [49]. The morphological differences between Travisiinae and the other two subfamilies were further supported by Belova and Zhadan [50]. These authors suggested that the presence of several shared anatomical and ultrastructural features of the gills amongst several opheliid genera but absent in Travisia, might support the exclusion of the latter from Opheliidae and would constitute synapomorphies of the Opheliinae and Ophelininae. The Travisiidae is now considered the sister group to the Scalibregmatidae, while molecular analyses have highlighted the affinities of opheliids to capitellids and echiuroids [51,52] and to other "sedentary" families as well (e.g., Arenicolidae). Therefore, today Opheliidae includes only the subfamilies Opheliinae and Ophelininae [1,46]. The two subfamilies are represented only by species with elongated bodies and smooth cuticle, all sharing the presence of a conspicuous ventral groove [1].

According to Blake and Maciolek [1], Opheliidae comprises five genera distributed in the subfamilies Opheliinae (Ophelia and Thoracophelia Ehlers, 1897) and Ophelininae (Armandia Filippi, 1861, Ophelina and Polyophthalmus Quatrefages, 1850). However, there has been much confusion with the generic arrangement within the Opheliidae (e.g., synonymies and changes in diagnosis of genera). Sene-Silva [53] performed a cladistic morphological analysis of the family that have led to a redefinition of the previously established genera. In this context, Lobochesis Hutchings and Murray, 1984 was synonymized with Thoracophelia, which subsequently replaced Euzonus Grube, 1866 (a homonym of the diplopod myriapod Euzonus Menge, 1854 [54]). According to Blake and Maciolek [1], the genera Tachytrypane McIntosh, 1879 and Ammotrypanella would fall within the current diagnosis of Ophelina because the presence and distribution of branchiae seemed much variable within the latter. However, Ammotrypanella was retained by Wiklund et al. [2] who also amended the redefinition of the genus as given by Schüller [55]. Furthermore, the abranchiate Antiobactrum Chamberlin, 1919 is regarded as a valid genus in the World Register of Marine Species [3] but considered, in turn, as a synonym of Ophelina by Blake and Maciolek [1]. In this context, Paul et al. [46] have provided a phylogenetic analysis of the family but considering only a limited number of species; therefore, an analysis based on molecular and morphological characters including a greater taxa sampling would be desirable to assess the actual definition of genera.

\subsubsection{Taxonomic History}

The first described species was Ophelia bicornis Savigny, 1822. The number of newly described taxa increased gradually during the second half of the 19th century and along the first two decades of the 20th century. After WWII new species were described at a rate of about 10 per decade, whereas in the last decade (2010-2019) 30 new species were added to the family from all around the globe (Figure 2A). This overall tendency closely resembles those exhibited by each of the most speciose genera (Figure 3). 

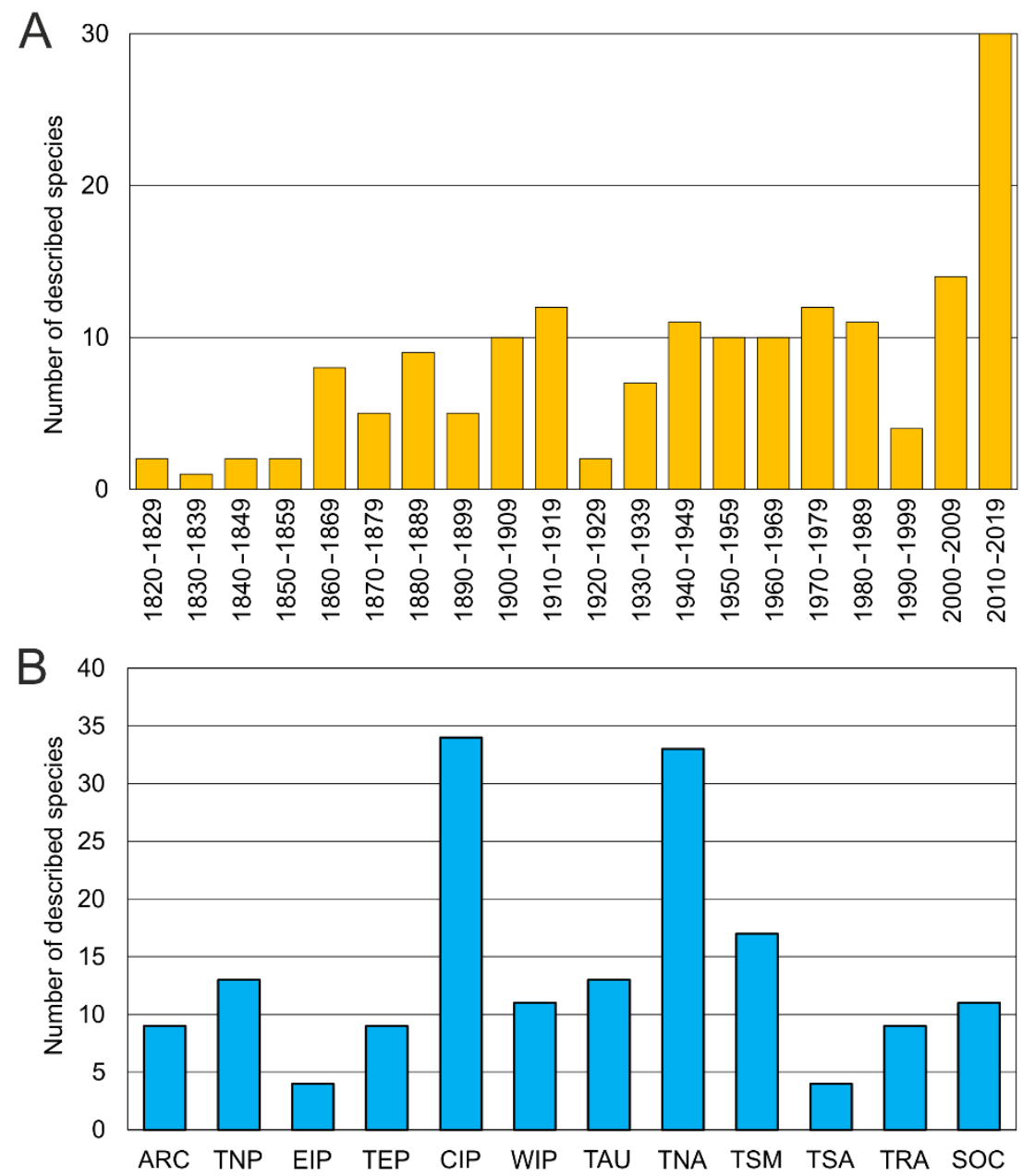

Figure 2. (A) number of opheliid species described per decade; (B) number of valid opheliid species listed under the bioregion (sensu Spalding et al. [45]) according to type locality. Abbreviations: ARC-Arctic; TNP-Temperate North Pacific; EIP-Eastern Indo-Pacific; TEP-Tropical Eastern Pacific; CIP-Central Indo-Pacific; WIP—Western Indo-Pacific; TAU—Temperate Australasia; TNATemperate Northern Atlantic; TSM-Temperate South America; TSA-Temperate South Africa; TRA-Tropical Atlantic; SOC—Southern Ocean.

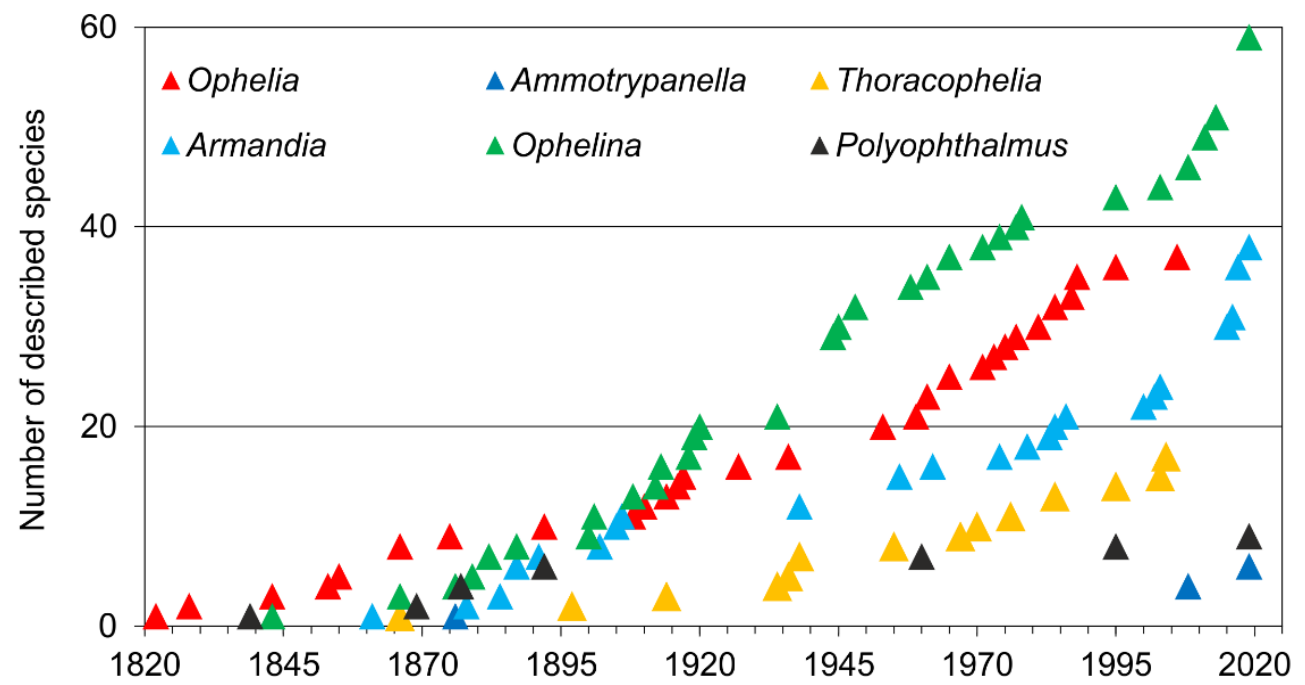

Figure 3. Number of described species (accumulated) of each opheliid genus (including Ammotrypanella) from 1820 to 2020 . 
There are a number of identification keys for Opheliidae from regions such as South Africa [56], California [47], the United Kingdom [54], and the Iberian Peninsula [4]. Some papers also provided tables that compile morphological features for species of the genus Thoracophelia (as Euzonus and Lobochesis; [57]), Ophelina from Australia [58], Armandia [59] and Polyophthalmus [60], and identification keys for Ophelina from NE Atlantic [61] and Armandia from Australasia and Central Indo-Pacific [62,63].

\subsubsection{Taxonomic Characters and External Morphology}

The opheliid body is usually elongated and divided into a defined number of segments, usually ranging between 30-70. The anterior end is inflated in the Opheliinae, but typically sleek and more elongate in the Ophelininae $[1,4]$. The trunk may be entire, as in Ophelininae (Figure 1A,D,E), or divided in two (e.g., Ophelia) (Figure 1C) or three regions (e.g., Thoracophelia) (Figure 1B). In Thoracophelia, the modified chaetiger 10 marks the limit between the thoracic and the abdominal region (Figure 1B). A conspicuous ventral groove is always present, but it may extend continuously throughout the trunk, as in Ophelininae (Figure 1A,D and Figure 4B,H,I), or be restricted to its posterior half, as in Opheliinae (Figure 1C). Some species present two additional longitudinal lateral grooves, one on each side of the body (Figure $4 \mathrm{H}$ ). Paired lateral branchiae attached dorsally to the parapodia are present in many species, either along the entire trunk or limited to its posterior $1 / 2-2 / 3$ portion. Branchiae are always absent in last few chaetigers (Figure 1B,E, Figure 4I,J and Figure $5 \mathrm{~A}, \mathrm{C}, \mathrm{H})$. Branchiae are bifurcate or pectinate in some Thoracophelia, but simple and cirriform in the remaining genera (Figure 1B).
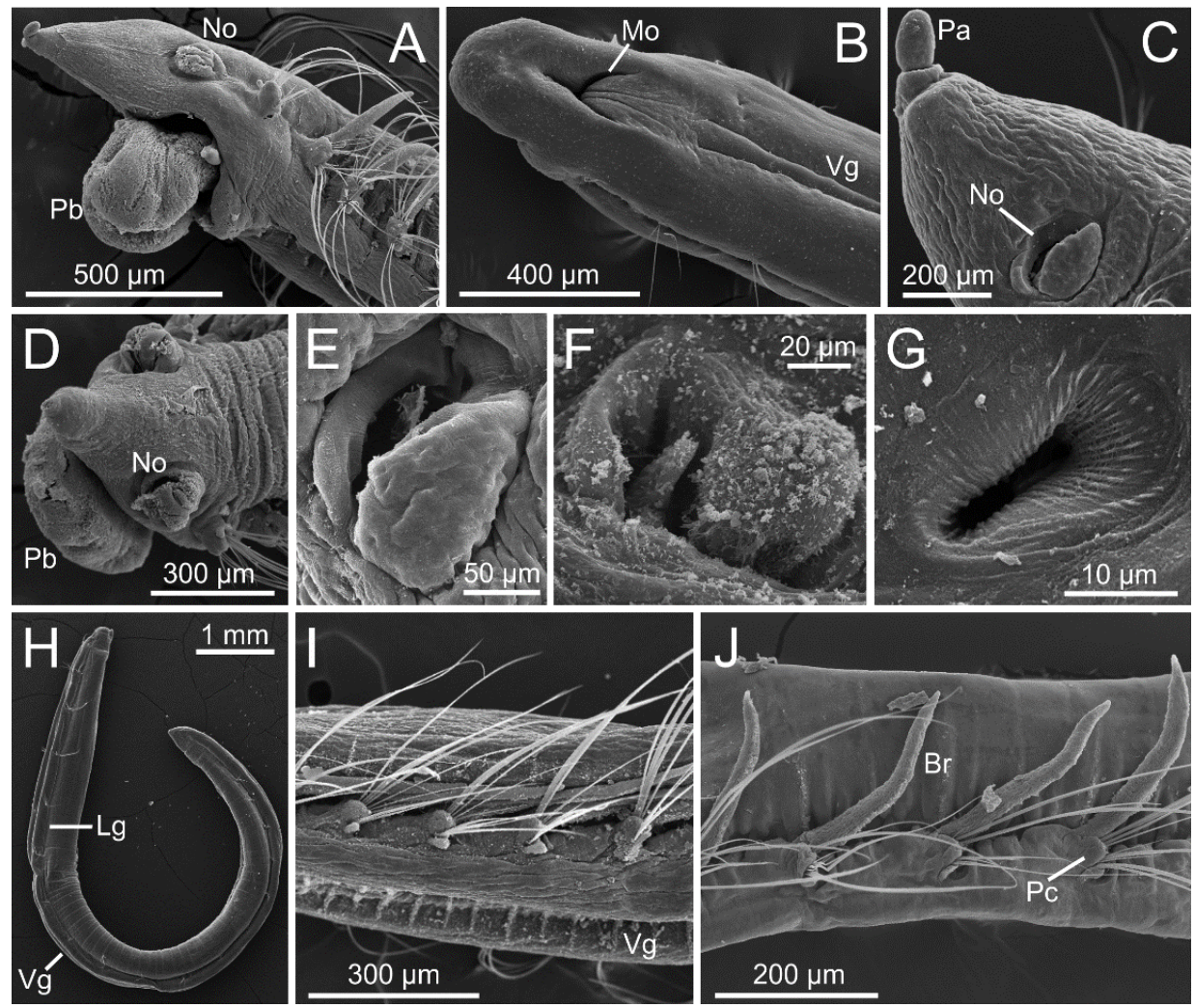

Figure 4. SEM micrographs of several Opheliidae showing main diagnostic characters. (A) Ophelina breviata, anterior end in lateral view, showing pointed prostomium; (B) Polyophthalmus pictus, anterior end in ventral view, showing the distally rounded prostomium; (C) Ophelina helgolandiae, anterior end in lateral view; (D) O. breviata, anterior end in dorsal view; (E) O. helgolandiae, nuchal organ; (F) Armandia buccina, nuchal organ; (G) Ophelina abranchiata, nuchal organ; (H) O. abranchiata in lateral view; (I) A. buccina, anterior chaetigers in lateral view; (J) Armandia opisthoculata, mid-body chaetigers in lateral view. Abbreviations: $\mathrm{Br}$-branchia; Lg-lateral groove; Mo-mouth; No-nuchal organ; $\mathrm{Pa}$ - palpode; $\mathrm{Pb}$-proboscis; Pc-prechaetal lobe; $\mathrm{Vg}$ - ventral groove. 

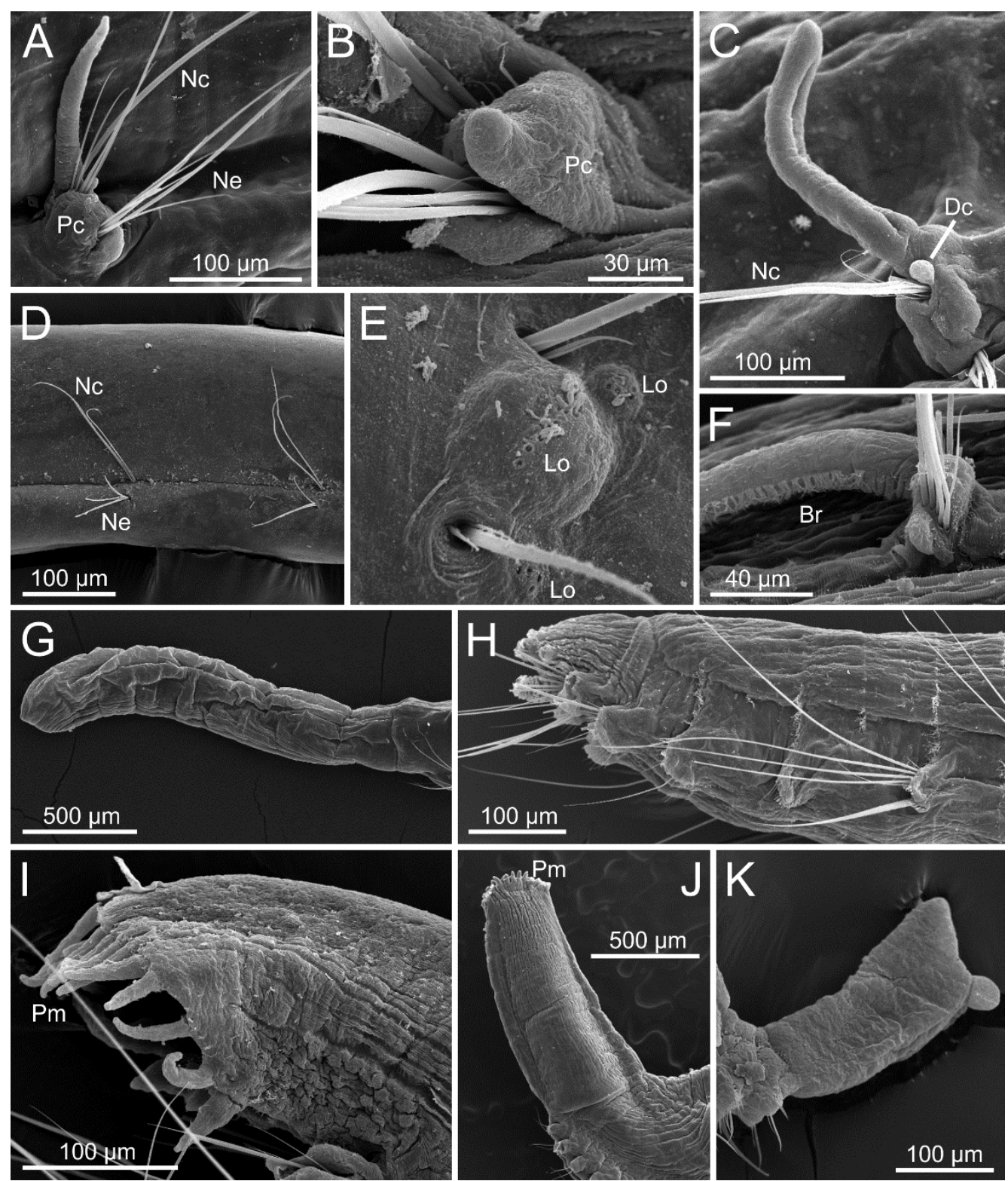

Figure 5. SEM micrographs of several Opheliidae showing main diagnostic characters. (A) Ophelina basicirra, parapodium and branchia; (B) Armandia laminosa, parapodium; (C) Ophelina helgolandiae, parapodium and branchia; (D) Ophelina abranchiata, mid-body parapodia; (E) Polyophthalmus pictus, lateral organs; (F) Armandia paraintermedia, parapodium and branchia; (G) O. abranchiata, anal tube in lateral view; (H) Armandia parva, posterior end in lateral view; (I) Armandia tubulata, anal tube in lateral view; (J) Ophelina bowitzi, anal tube in lateral view; (K) Ophelina cylindricaudata, anal tube in lateral view. Abbreviations: $\mathrm{Br}$ —-branchia; Dc—“dorsal cirrus"; Lo-lateral organs; Nc—notochaetae; Ne—neurochaetae; Pc—prechaetal lobe; Pm—pygidium marginal papillae.

The prostomium is elongated, tapered, or conical in most species (Figure 4A,C), but rounded in Polyophthalmus (Figure 4B). It lacks lateral appendages, but a terminal palpode (sometimes biarticulated) is present in Armandia and several Ophelina species (Figure 4A,C). The proboscis is often an axial, nonmuscular eversible structure (Figure 4A,D and Figure $6 \mathrm{~A}, \mathrm{~B})$, but it might consist of several retractable ciliated tentacles in some species of Armandia $[63,64]$. Nuchal organs are eversible and represented by one pair of conspicuous ciliated pits/slits of various shapes depending on the species [65] (Figure 4A,C-G). Exceptionally, two pairs of nuchal organs are present in Polyophthalmus spp. and Armandia polyophthalma Kükenthal, 1887 (see [65]), often slightly pigmented [2]. Subdermal pigmented eyes (two to three) are present in several species [66] (Figure 1E); these simple eyes are present in larvae 
and may be retained in the adult [67]. Additional pairs of segmentally arranged pigmented eyes are present in Armandia and Polyophthalmus, at least on several midbody segments (Figure 1E).

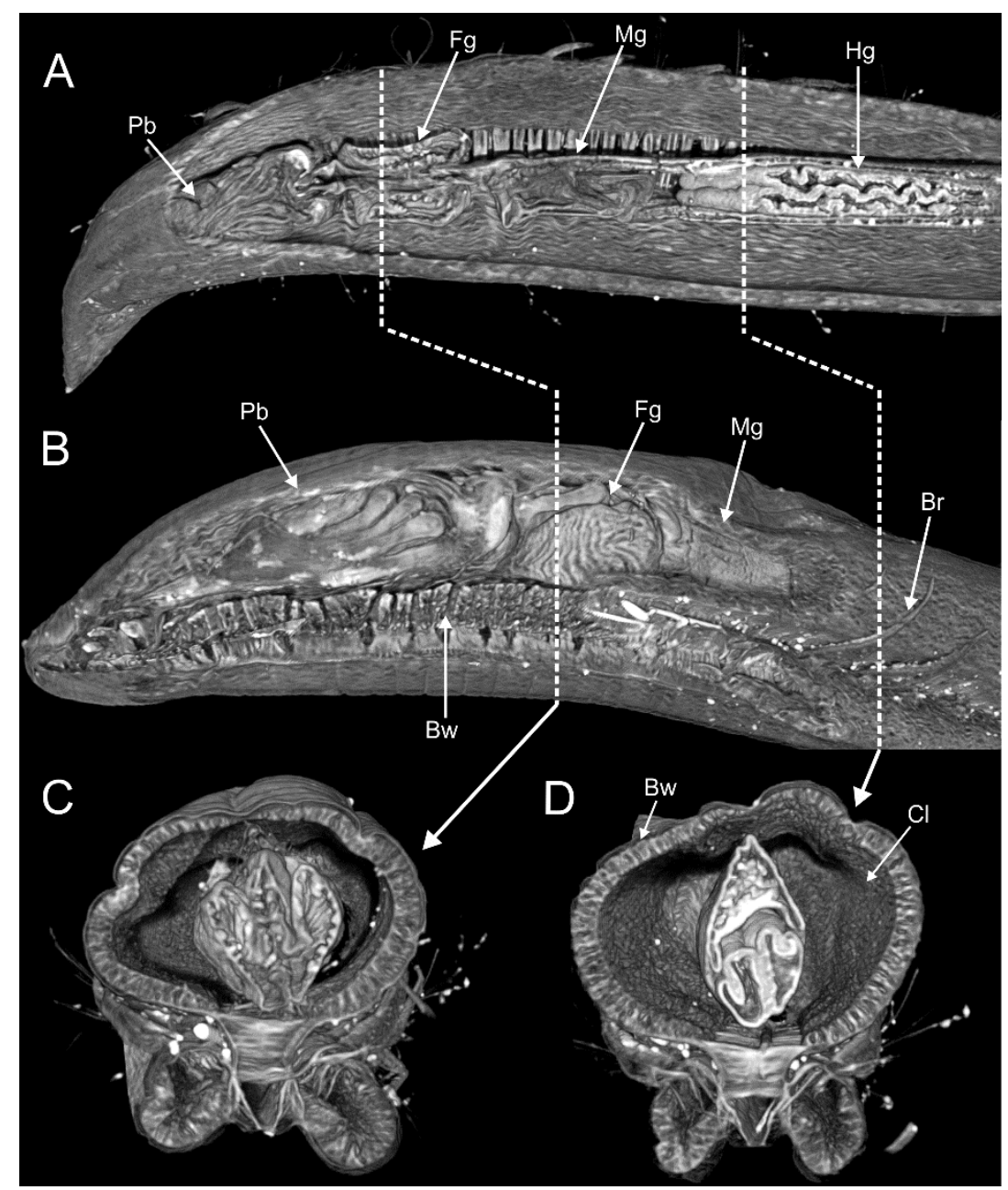

Figure 6. Microcomputed tomography $(\mu \mathrm{CT})$ sections of Ophelina acuminata from Iceland. (A) frontal, (B) right sagittal and $(\mathbf{C}, \mathbf{D})$ transversal body sections showing internal anatomy. White discontinuous lines in $(\mathbf{A}, \mathbf{B})$ marking regions showed in $(\mathbf{C}, \mathbf{D})$. Abbreviations. Br-branchia; Bw-body wall musculature; $\mathrm{Cl}$-coelomic space; $\mathrm{Fg}$ - foregut; $\mathrm{Hg}$ - hindgut; $\mathrm{Mg}$ - midgut; $\mathrm{Pb}$ - proboscis.

Parapodia are biramous and consist of small lobes or tori provided with simple capillary chaetae (Figure 4I,J and Figure 5A-F). A ventral cirrus is present and a small spherical projection may be also found dorsally on the prechaetal lobe in Armandia (termed as "dorsal cirrus": [15,62]; Figure 5C). Parapodial ciliated sensory organs were reported on the prechaetal lobe in several species of Armandia [62]. Lateral organs are usually present as ciliated pits in between noto- and neuropodia and may also occur in the anterior achaetous segments [15] (Figure 5E).

The last segments may be achaetous and are often retractile. The pygidium typically prolongs into a tubular funnellike structure (termed anal cone, funnel, or tube) that may be quite long in comparison to body length in some species of Ophelininae (Figures 1D and 5G-K). The shape of the funnel, as well as the presence of accessory structures, such as dorsal/marginal papillae and unpaired/paired cirri, diagnoses few genera and species (Figure 1C-E and Figure 5G-K).

Most opheliids have a relatively simple body, reduced parapodia, and simple chaetae. Therefore, the taxonomy of the family has traditionally relied on the limited number of available external characters. This is particularly evident among Polyophthalmus, a 
genus in which most described species are nearly identical morphologically (e.g., [19]). Opheliid genera are defined according to whether the body is divided in distinct regions or not, the extension of the ventral groove, as well as the presence of branchiae and lateral eyes. Species are instead diagnosed based on several parapodial features (e.g., shape of prechaetal lobe, ventral cirrus and presence of "dorsal cirrus", relative length of chaetae across body), the number of lateral eyes (if present), the length of the branchiae, as well as the number of branchiate segments and pygidial cirri. Features of the anal tube are mainly relevant to identify species of Ophelininae, and include its shape, length relative to last chaetigers, number and shape of marginal anal cirri/papillae, as well as presence, shape, and position of the unpaired ventral cirrus and the paired basal cirri [58]. Unfortunately, the fact that branchiae and anal tube are easily detached has generated much confusion regarding the taxonomic status and identifications of some opheliid taxa (e.g., [2]). The many species described based on single/damaged specimens have contributed to worsen the situation [58], together with the lack of information on the intraspecific variation exhibited by some characters, such as number and presence of lateral eyes and anal tube papillae, which may change through different ontogenetic stages in the same species [66]. Examination of a sufficient number of specimens of several sizes is therefore crucial to alleviate this situation in the future $[2,58,66]$.

Parapar et al. [15] suggested that features of nuchal and lateral organs might represent useful characters to diagnose species in the future, in spite that the latter, for instance, can be easily overlooked or is difficult to examine due to state of preservation [2]. In this context, the use of SEM for examination of properly fixed specimens seems mandatory to fully assess features of parapodia, as well as nuchal and lateral organs (e.g., $[2,58,60,62,63,68]$ ).

\subsubsection{Internal Morphology}

The internal anatomy of opheliids has been studied mostly in several intertidal species $[16,17,69]$, including later detailed accounts on the structure of the proboscis [64], body musculature [20,21], respiratory system [50], and sensory organs (see below).

Opheliids lack circular muscle fibers, but they possess bands of longitudinal muscles protruding along the body surface [20], as well as oblique muscles that insert into the midventral line thereby contributing to shape the typical opheliid ventral groove. The structure of the proboscis varies greatly among taxa, corresponding to several of the types described by Tzetlin and Zhadan [64]: type 1, symmetrical, bubblelike, and ciliated as found in the Opheliinae; type 3, asymmetrical, dorsal-lobed (e.g., Ophelina, Polyophthalmus); type 4, formed instead by several retractable ciliated tentacles (some species of Armandia). Exceptionally, the proboscis of Armandia amukusaensis Saito, Tamaki and Imajima, 2000 has been reported as flanked by several "filaments" [66]. The digestive tract, and particularly the intestine, might be regionalized in certain species [70] (Figure 6).

The circulatory system is closed [17]. Gills appear as body wall protrusions containing coelom or vessels connected to blood sinuses [50]. Metanephridia are present in several species [71], although protonephridia have been reported in Thoracophelia mucronata (Treadwell, 1914) by McConnaughey and Fox [17]. The ultrastructure of sensory organs has been described thoroughly in several opheliids, including the nuchal organs in Ophelia bicornis [72] and Ophelia rathkei McIntosh, 1908 [65]), the subdermal eyes in Armandia brevis (Moore, 1906) [18] and the juveniles of O. rathkei [67], as well as the lateral eyes in A. brevis [73], P. pictus, and Polyophthalmus qingdaoensis Purschke, Ding and Müller, 1995 [19].

In this sense, the consistent differences in the ultrastructure of lateral eyes in Polyophthalmus (e.g., size and number of cells, number, and dimensions of cellular elements) seem also useful to distinguish species [19]. Thus, future ultrastructural studies might provide phylogenetically informative morphological characters, perhaps further illuminating the delineation of genera. In the same line, the use of micro-CT seems a promising source for phylogenetically informative characters insofar as it offers a comparatively easy overview of the internal anatomy and produces a minimum damage to the examined specimen (e.g., [74]) (Figure 6). It therefore represents a useful tool to compare, for instance, the 
regionalization of the digestive tract as well as the organization of the circulatory system across genera and/or species.

\subsubsection{Species Diversity and Distribution}

The most speciose genera are Ophelina (about 59 species, excluding Ammotrypanella), Armandia (38) and Ophelia (37); Thoracophelia comprises 17 species. Depending on the sources, Polyophthalmus is composed of four [3] to nine [60] species, highlighting the need for further morphological and molecular work in order to assess its actual diversity as well as a fully review the synonyms and material attributed worldwide to Polyophthalmus pictus $[4,60]$. Finally, six species are classified into Ammotrypanella by those authors who consider the genus as valid $[2,15,55]$.

Opheliids have been reported or described from the poles to the equator across all the 12 marine ecoregion realms defined by Spalding et al. [45] (Figure 2B). Similar distribution patterns are found in the genera Armandia, Ophelia, and Ophelina; whereas Thoracophelia is mostly restricted to the temperate realms (14 out of 17 species). Many opheliid species have been described from Temperate Northern Atlantic and Central Indo-Pacific (33 and 34 , respectively) in comparison to other regions (ranging from 4 to 17). The type localities of half of the known species of Ophelia (16) are in the Temperate Northern Atlantic and about one third of each Armandia and Ophelina are found in the Central Indo-Pacific. These numbers, however, may be explained by the greater sampling effort historically performed in those areas and the subsequent more detailed knowledge that we have on their annelid faunas of the NW and NE Atlantic, California, and some areas of the Pacific Ocean $[47,75]$. Indeed, recent work done in unexplored Pacific areas has yielded many new taxa. For instance, Magalhães et al. [60] have described five new species from several western Pacific islands and Wiklund et al. [2] eight new species of Ammotrypanella and Ophelina plus other still formally undescribed taxa from the eastern Clarion-Clipperton Zone (central Pacific). Furthermore, Parapar and Moreira [62] and Moreira and Parapar [63] have described eleven new species of Armandia from Lizard Island (Great Barrier Reef) whereas only two valid species of this genus are present in the comparatively better-known Western Europe. These findings suggest that the actual diversity in other temperate and tropical regions may be greater, including other Pacific areas as well as Temperate Australia (only 13 species described so far) and Tropical Atlantic (nine species).

A wide geographic distribution has been reported for species such as P. pictus, Armandia intermedia Fauvel, 1902, Ophelina acuminata Örsted, 1843 and O. abranchiata Støp-Bowitz, 1948. However, these taxa might represent complex of cryptic species as suggested by recent molecular analyses of several populations previously attributed to $O$. abranchiata $[2,76]$. On the contrary, many taxa have not been reported after original description thus making it difficult to assess their distribution patterns. Finally, reports of species far away from their type locality should be considered with caution because of the lack of knowledge of local faunas (see [60]).

\subsubsection{Biology and Ecology}

Most Ophelia species inhabit clean sandy sediments from the intertidal fringe to the shallow subtidal down to depths of about $100 \mathrm{~m}$ [75]. The exception is Ophelia profunda Hartman, 1965 and Ophelia pulchella Tebble, 1953 that prefer, in turn, muddy bottoms; the former being reported down to $1700 \mathrm{~m}$ depth. Species of Armandia, Polyophthalmus, and Thoracophelia prefer coastal areas, the only remarkable exception being Thoracophelia profunda (Hartman, 1967) (4000 m). Polyophthalmus translucens Hartman, 1960 has been reported at depths of $900 \mathrm{~m}$ but Sene-Silva [53] suggested that this species may correspond to the genus Ophelina. Indeed, Ophelina shows a wider range of ecological preferences, with some species restricted to intertidal-shallow depths while others show wide bathymetric ranges (subtidal/shelf depths down to 2000-3000 m), or, alternatively, are limited to the deep-sea (at depths below $1000 \mathrm{~m}$ ). Ammotrypanella species are distributed at depths below $400 \mathrm{~m}$, more than reaching the abyssal realm. 
The majority of opheliids burrow in coarse to fine sand or in muddy sediments. Ecology of several intertidal species of Armandia, Ophelia, and Thoracophelia have been extensively studied when compared to deep-sea species [13]. Some opheliids such as Thoracophelia furcifera Ehlers, 1897 and T. mucronata may reach high abundances in the intertidal of sandy beaches (2000-40,000 individuals per $\mathrm{m}^{2}$ [8,17]). Spatial variations in abundance have been related to beach morphodynamics, granulometry, and organic content (e.g., [10]). Experimental work has suggested that the abundance of $A$. brevis is correlated negatively with proliferation of tube-building infaunal species [77]. In general, opheliids are found within well-oxygenated sediments but some Ophelina species thrive in muddy sediments with low oxygen content [50] or a high concentration of heavy metals [58]. On the other hand, P. pictus usually dwells among intertidal algae, reaching densities that surpass 5000 ind. per $\mathrm{m}^{2}$ in Cystoseira mats where is also present all the year round [78]; Polyophthalmus is also found among fouling communities in artificial habitats [79].

Opheliids show two strategies to burrow into the sediment, i.e., peristalsis based on oblique muscular fibers acting in conjunction with cuticular fibers (e.g., Thoracophelia) resulting in a dual anchor burrowing mechanism $[9,21]$ or, rather, by undulatory movements (e.g., Armandia). Regarding the latter, A. brevis lacks circular musculature and therefore relies on bands of oblique muscles that act antagonistically to longitudinal muscles. This muscular arrangement allows for lateral bending and undulating movements that rearrange the sediment grains around by creating a burrow [80]. Armandia brevis and other Ophelininae species display a similar pattern of movement when swimming in water; while there is no report of such behavior in Opheliinae.

These burrowing abilities facilitate the migration of intertidal species of Thoracophelia downwards or upwards into the sediment to cope with wave turbulence or avoid of low levels of oxygen in the interstitial water [81]. Thoracophelia is also capable to migrate horizontally seaward or landward into the sediment in response to changing beach morphodynamics in high-energy environments [7]. Vertical migration in Ophelia has also been related to the release of gametes/eggs near the sediment surface [82] or to the avoidance of interspecific competition [83]. Tamaki [84] reports that specimens of Armandia sp. migrate in offshore direction as they grow. Giangrande et al. [10] has suggested that the spatial migration in Ophelia barquii Fauvel, 1927, from the upper intertidal to upper infralittoral zones, may occur as a response to seasonal changes in hydrodynamics. Because of their burrowing activity, opheliids are important agents in sediment bioturbation [6].

Opheliids are nonselective deposit-feeders by swallowing sediment with the everted proboscis [85]. Feeding behavior has been studied in several species of Ophelia, Ophelina, and Thoracophelia; intertidal and shallow-water species show high ingestion rates [86]. On the contrary, P. pictus has been suggested to be a selective feeder [87].

In general, opheliids are mostly dioecious and synchronously release large amounts of gametes or eggs [88]. Life cycle and reproduction of several Ophelia species has been studied in North Atlantic and the Mediterranean. Life span extends from one to six years and reproduction occurs from spring to autumn. In general, species breed once a year. On the other hand, adults of $A$. brevis and P. pictus experience an epitokous planktonic phase in which they swimming into water to release their gametes $[89,90]$. Presence of similar epitokous phases has also been suggested for A. polyophthalma at least in aquarium conditions. Epitokous specimens show longer chaetae on the posterior five chaetigers that are in turn slightly compressed laterally [90].

Larvae might go through a short lecithotrophic planktonic stage of 4-12 days [5,10,82] or a longer planktonic life thus allowing for a greater dispersal ability (e.g., A. brevis; $[89,91]$ ). Larvae of Ophelia, Thoracophelia, Armandia cirrhosa Filippi, 1861, and A. polyophthalma consist only of two to five chaetigers right before settlement whereas those of $A$. brevis may have up to 20 segments $[87,89,90,92,93$ ]. Miner et al. [91] described the feeding mechanisms of the larvae of $A$. brevis that includes action by ciliary bands and direct ingestion with the mouth. After this pelagic phase, the larva settles on the substrate and the body enlarges to become a juvenile worm. Wilson [94] has demonstrated, after several experiments that the 
settlement of $O$. bicornis larvae is conditioned by the presence of bacteria in the sand grains rather than by the grain size itself.

Polyophthalmus pictus is among the few polychaetes unable to regenerate body segments although it may show wound healing of posterior segments [95].

Deep-sea opheliids are known to be the hosts of two parasitic cyclopoid copepod species of the genus Ophelicola [96]. Opheliids are also consumed by several fishes and crabs; for example, Ophelia limacina (Rathke, 1843) has been found in the digestive tract of demersal fishes [97] and P. pictus in Trachurus mediterraneus (Steindachner, 1868) [98]. Kicklighter and Hay [99] also suggested that A. agilis may have some chemical deterrents that make it unpalatable for some fishes.

Some opheliids have been the subject of a number of ecotoxicological studies by exposing them in experimental conditions to contaminants (e.g., heavy metals) or antifouling compounds (e.g., tributyltin) in sediments. For instance, O. bicornis has been demonstrated to be sensitive to cadmium [12] whereas the exposition of $A$. brevis to TBT resulted in changes in body growth rates [11]. Armandia agilis (Andrews, 1891) has been suggested as an appropriate target species to discriminate between clean and contaminated sediments [100] and Armandia cyprophilia Neave and Glasby, 2013 is abundant in sediments with high concentrations of copper in otherwise depauperated polychaete assemblages [58]. Therefore, the use of opheliids as indicators of marine pollution seems a promising field of study.

\subsection{Scalibregmatidae Malmgren, 1867}

\subsubsection{Systematics}

The first described scalibregmatid was Scalibregma inflatum Rathke, 1843 [30], originally classified as an allied to the genus Arenicola Lamarck, 1801 [24], until Malmgren [101] established the family Scalibregmatidae in 1867. Later classifications considered Scalibregmatidae as part of the suborder Opheliida [97,102]. This placement was congruent with the results of subsequent morphological analyses, which nested Scalibregmatidae within the clade Scolecida as sister group of Opheliidae, although without any synapomorphy [44]. In contrast, molecular data have more frequently favored a sister-group relationship between Scalibregmatidae and Arenicolidae, often including the genus Travisia Johnston, 1840 [46,103], nowadays classified as a separated family [23]. However, the placement of Scalibregmatidae must be considered unresolved, as those analyses were limited to few molecular markers and did not include morphological information. Despite phylogenomic information is available for at least one species in the family [104], Scalibregmatidae has never been included in broad phylogenomic analyses [105].

Scalibregmatidae comprises about 68 described species and 14 valid genera [23]. However, there has been much confusion regarding the species composition of several of them, hampered by the fact that many scalibregmatid species have been described based on incomplete specimens or limited material [27,40]. Scalibregmatids have been traditionally categorized as arenicoliform or maggotlike depending on their overall body shape, although without assigning to these groups any systematic value. Arenicoliform species are typically elongated, inflated in the anterior end, and tapering towards the pygidium; whereas maggotlike species are shorter and stouter [31]. This distinction has been progressively abandoned partly because we know that these differences often rely on preservation artefacts and post mortem contraction; but mostly because intermediate forms also exist and this character even changes during the development of certain species $[26,36]$.

There have been no attempts to resolve the internal relationships of Scalibregmatidae apart from few studies aiming at placing a few specific taxa $[2,26,46,103]$, so the character evolution within the group remains unknown [43].

\subsubsection{Taxonomic History}

The study of Scalibregmatidae received a notable attention during the 19th century. By the beginning of the 20th century, many common European species were already de- 
scribed [30,106-110] including also a few species from Australia [111], New Zealand [112], Cuba [113], and South Africa [111] (Table A2). This level of attention did not decline during the 20th century, when new species of Scalibregmatidae were described nearly every decade (Figures 7A and 8).

A

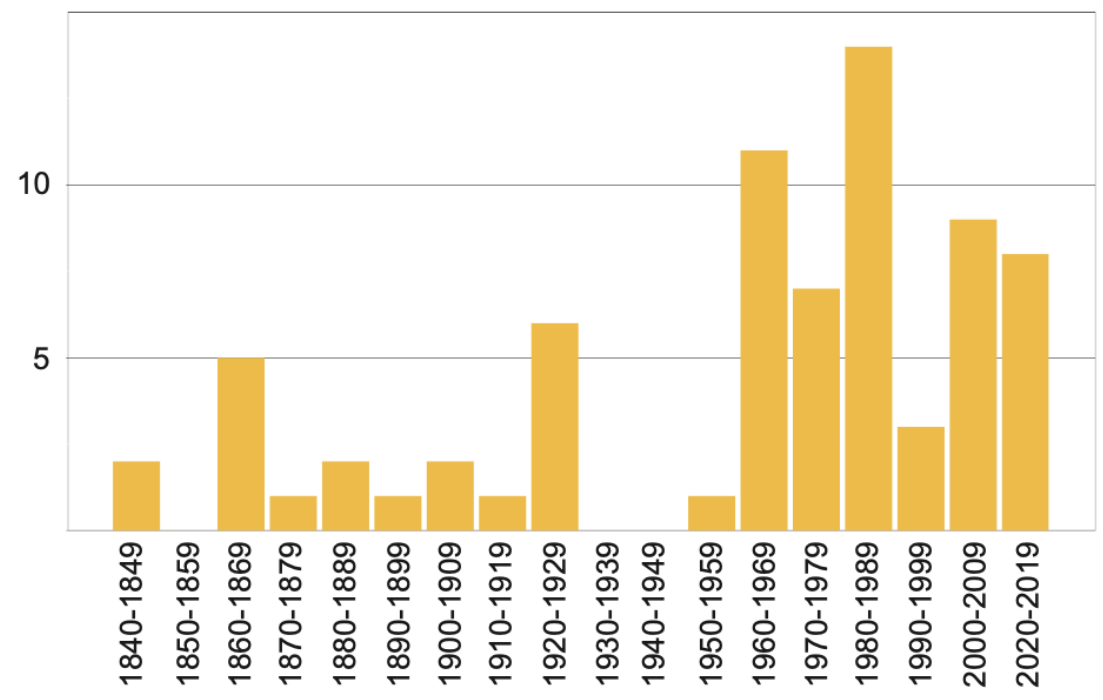

B

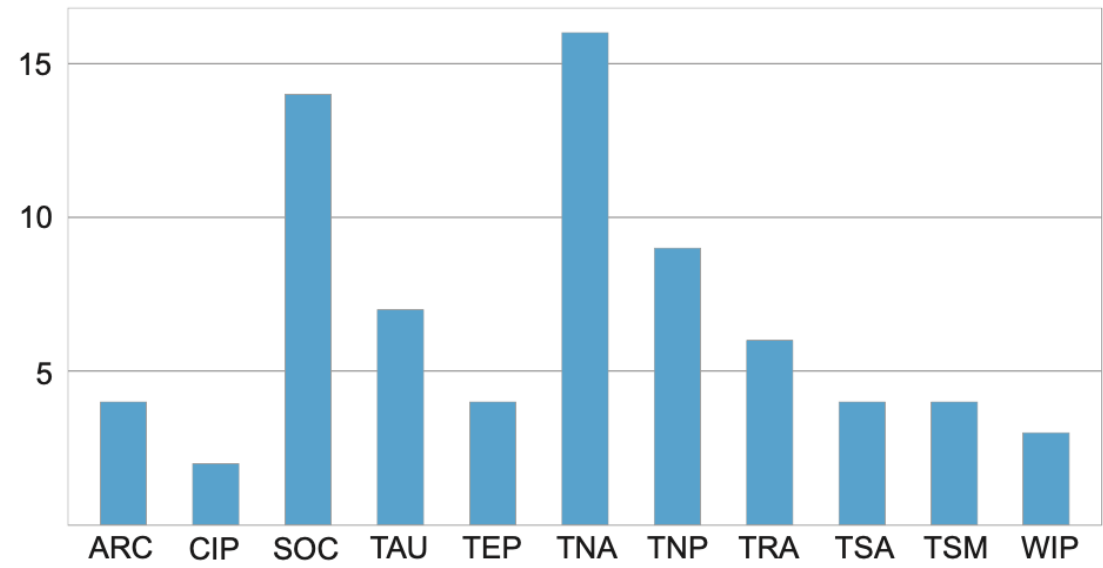

Figure 7. (A) number of scalibregmatid species described per decade; (B) number of valid scalibregmatid species listed under the bioregion (sensu Spalding et al. [45]) according to type locality. Abbreviations: ARC—Arctic; CIP-Central Indo-Pacific; SOC—Southern Ocean; TAU—Temperate Australasia; TEP-Tropical Eastern Pacific; TNA-Temperate Northern Atlantic; TNP—Temperate North Pacific; TRA—Tropical Atlantic; TSA-Temperate South Africa; TSM-Temperate South America; WIP-Western Indo-Pacific. 


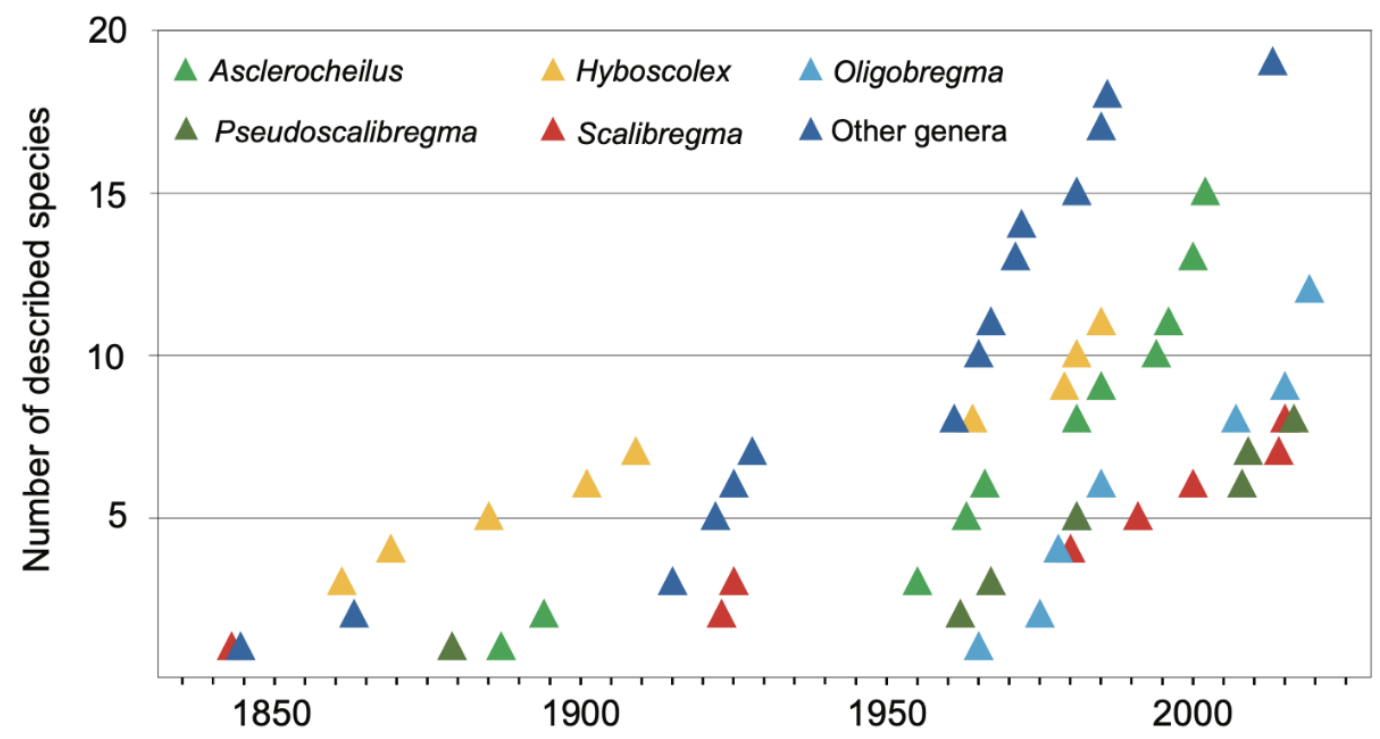

Figure 8. Number of described species (accumulated) of the main scalibregmatid genera from 1820 to 2020. Genera with less than five described species have been grouped under "Other genera".

The first major revision for the family was published in 1925 [114], followed by the work by Kudenov and Blake [38], Kudenov [25] and Blake [31,36,47]. There have also been important works focused on individual genera, such as Axiokebuita Pocklington and Fournier, 1987 [26,61], Oligobregma Kudenov and Blake, 1978 [37], and Scalibregma [35,36]. The status of the systematics of the family has been recently reviewed by Blake [23], who has summarized and amended the diagnoses of all the currently valid genera.

\subsubsection{Taxonomic Characters and External Morphology}

Members of Scalibregmatidae are relatively large annelids with few taxonomically informative characters. The prostomium is generally rounded or triangular, lacking antennae but often bearing a pair of lateral or frontal extensions, whose homology with palps remains unclear [43] (Figures 9 and 10B-E). Due to the presence of these structures, the prostomium has been often described as T-shaped [see 23]. Prostomial extensions are well developed in the species of Axiokebuita and Speleobregma Bertelsen, 1983, where they are separated from the prostomium by a basal furrow and bear longitudinal bands of motile ciliary bands capable of producing water currents (Figure 10D,E) [26]. Prostomial appendages are also long in the enigmatic Scalibregmella antennata Hartman and Fauchald, 1971, only known from its original collection off New England at 4800-5000 m depth [27], although the presence and arrangement of ciliary bands remain unknown (Figure 9G). In contrast, in the species of the genera Asclerocheilus Ashworth, 1901, Oligobregma, Scalibregma, and Sclerobregma Hartman, 1965 prostomial appendages consist of stiff hornlike prolongations, lacking ciliation and a basal furrow (Figure 9A,B) [31]. Despite these morphological differences, the fact that prostomial appendages follow a similar development in all investigated scalibregmatids suggests their homology across the family [26,36]. Epidermal eyes are sometimes present as simple ocelli (Figure 9F) or more complex structures composed of multiple ocelli (Figure 9B). Nuchal organs are usually small and often found retracted into grooves that extend transversally between the prostomium and the peristomium (Figure 10B,E). When they are everted, they resemble expanded bulbous vesicles [23]. Nuchal organs are associated with additional transverse bands of motile cilia in Axiokebuita cavernicola Martínez, Di Domenico and Worsaae, 2013 and Speleobregma lanzaroteum Bertelsen, 1983 [26] (Figure 9G, Figure 10D,E and Figure 11D). 

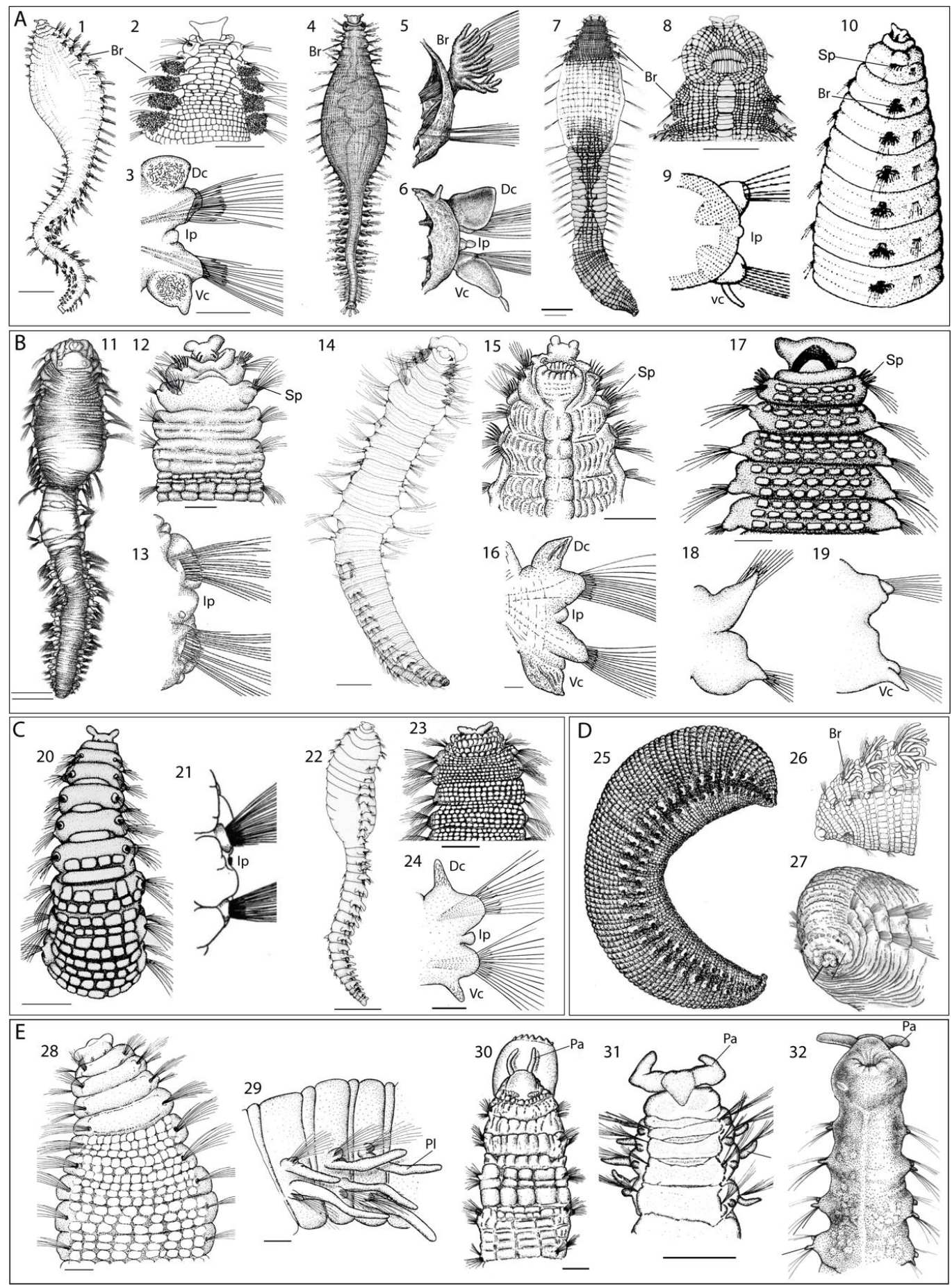

Figure 9. Stylized drawings showing the main taxonomic characters of different genera in Scalibregmatidae, artificially grouped according to the most conspicuous external traits. (A) Arenicoliform scalibregmatid genera with branchiae; genus Scalibregma, (1) S. hanseni, dorsal view, (2) S. inflatum, anterior end in dorsal view, (3) S. hanseni, left parapodium of chaetiger 21 in posterior view; genus Sclerobregma, (4) S. branchiatum, dorsal view, (5) chaetiger 3 in posterior view and (6) abdominal parapodium in anterior view; genus Cryptosclerocheilus, (7) C. baffinensis, dorsal view, (8) anterior end in ventral view; genus Parasclerocheilus, (9) P. capensis, chaetiger 40 and (10) anterior end in lateral view. (B) Arenicoliform scalibregmatids genera without branchiae and with spines; genus Asclerocheilus, (11) A. tasmanius, dorsal view, (12) A. kudenovi, anterior end dorsal view, (13) A. beringianus, chaetiger 15 in anterior view; genus Oligobregma (14) O. quadrispinosa, anterior view, (15) $O$. mucronata, anterior end in ventral view, (16) and posterior parapodium in anterior view; genus Sclerocheilus, (17) S. unoculus, anterior end in dorsal view, (18) chaetiger 16 in posterior view, and (19) chaetiger 29 in posterior view. (C) Arenicoliform scalibregmatid genera without branchiae and spines; genus Hyboscolex, (20) H. quadricincta, anterior end in dorsal view, (21) 
H. pacificus, median parapodium in anterior view; genus Pseudoscalibregma, (22) P. papilia, dorsal view, (23) P. usarpium, anterior end in dorsal view, (24) P. hartmanae, posterior chaetigers in anterior view. (D) Maggotlike scalibregmatids genera; genus Polyphysia, (25) P. crassa, lateral view and (26) anterior end in anterior view; genus Lipobranchius, (27), L. jeffreysi, frontal view. (E) Morphologically divergent genera; genus Scalibregmides, (28) S. peruanus, anterior end in dorsal view, (29) S. chilensis; genus Scalibregmella, (30) S. antennata, anterior end in dorsal view; genus Speleobregma, (31) S. lanzaroteum, anterior end in dorsal view; genus Axiokebuita, (32) A. minuta, anterior end in ventral view. Abbreviations: Br-branchiae; Dcdorsal cirri; Ip—interramal papillae or ciliation; $\mathrm{Pa}$ - prostomial appendages; $\mathrm{Pl}$-parapodial lobe; Sp—spines; Vc—ventral cirri. Modified from (1,3) Bakken et al. [35]; (2) Mackie [34], (4-6) Hartman [115], (7-8) Blake [116], (9-10) Day, [117], (11) Kirkegaard [118], (12) Blake [119], (13) Imajima [120], (14) Schüller and Hilbig [37], (15-16) Blake [36], (17-20) Kudenov [25], (21) Imajima [121], (22) Schüller [55], (23-24, 28-29) Blake [31], (25) Støp-Bowitz, [122], (26) Hartmann-Schröder [97], (27) Wesenberg-Lund [123], (30) Blake [23], (31) Bertelsen [124], (32) Parapar et al. [61].

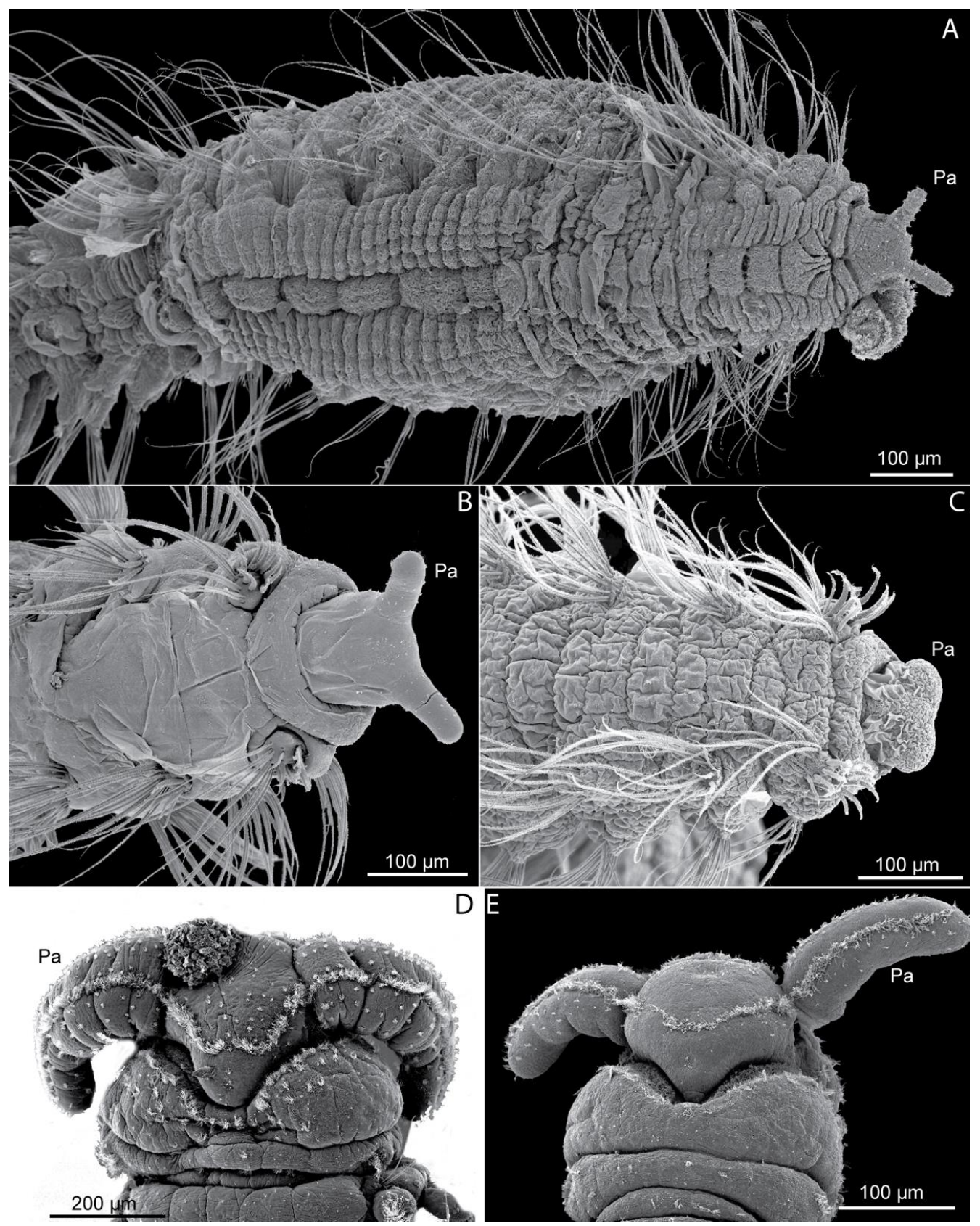

Figure 10. SEM micrographs of several Scalibregmatidae showing main prostomial diagnostic characters. (A) Pseudoscalibregma sp., Canary Islands, anterior end in ventral view, showing the pattern formed by the pads as well as the structure of the parapodia; (B) Asclerocheilus sp., Canary Islands, anterior end in dorsal view; (C) Asclerocheilus sp., northwestern Spain, 
anterior end in dorsal view; (D) S. lanzaroteum, anterior end in dorsal view; (E) A. cavernicola, anterior end in dorsal view. Notice the difference in the prostomial shape and appendages amongst (B-E), as well the presence of different development of the peristomium, and the presence of different types of chaetae. Abbreviation: $\mathrm{Pa}-$ prostomial appendages.

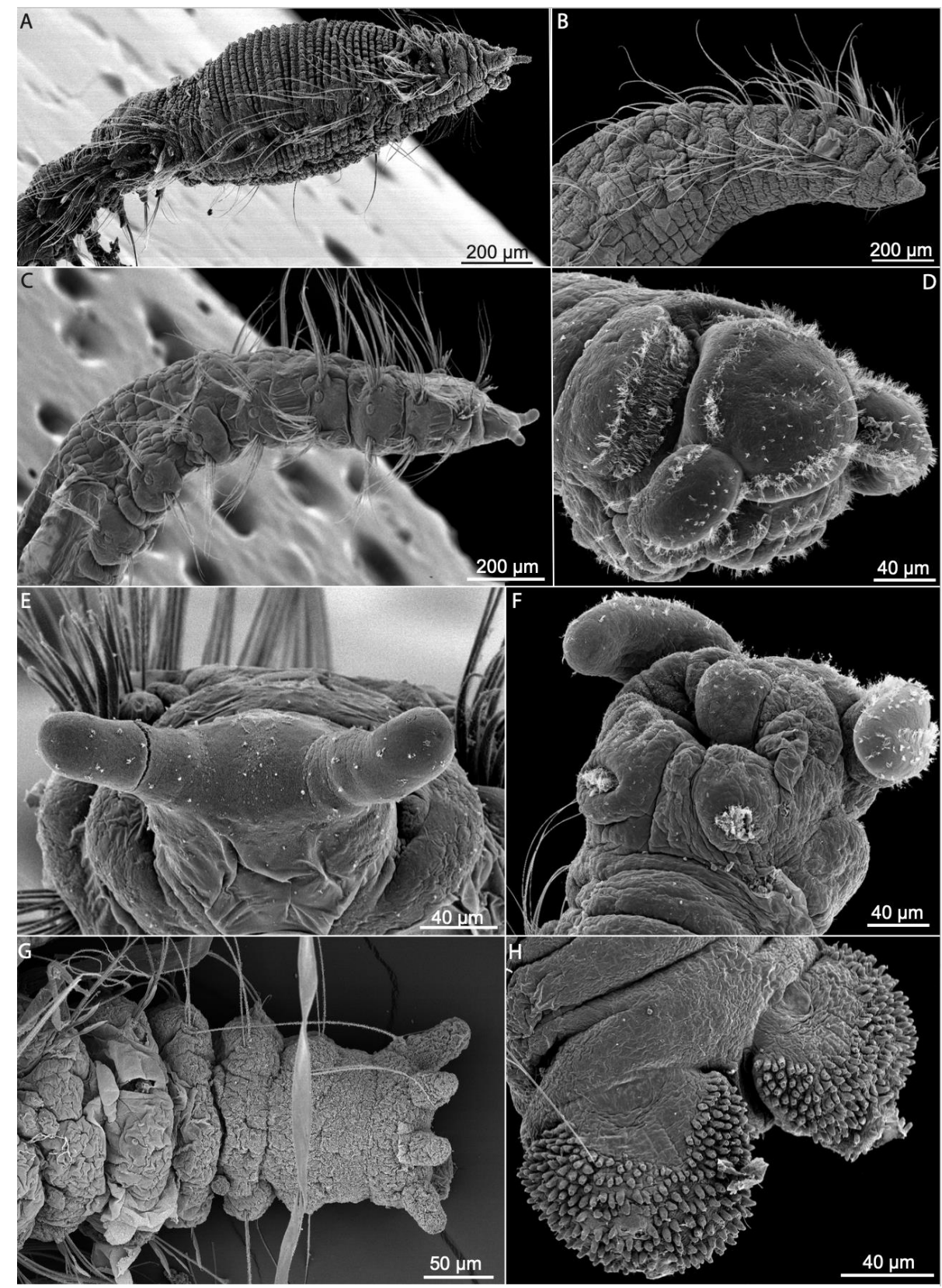

Figure 11. SEM micrographs of several Scalibregmatidae showing main diagnostic characters. (A) Pseudoscalibregma sp., Canary Islands, anterior end in lateral view; (B) Asclerocheilus sp., northwestern Spain, anterior end in lateral view; (C) Asclerocheilus sp., Canary Islands, anterior end in lateral view; notice the different morphology and epidermal pattern found on the anterior end on (A-C). (D) A. cavernicola, anterior end in lateral view; (E) Asclerocheilus sp., Canary Islands, anterior end in frontal view, compare the arrangement of the ciliary patterns between $(\mathbf{D}, \mathbf{E}) ;(\mathbf{F})$ A. cavernicola, anterior end in ventral view, showing the ventral ciliary pads pn the peristomium; (G) Asclerocheilus sp., northwestern Spain, posterior end in dorsal view, showing a typical shape and arrangement of the pygidium in Scalibregmatidae; $(\mathbf{H})$ A. cavernicola, posterior end in dorsal view, showing the adhesive pygidium typical of the genera Axiokebuita and Speleobregma. 
The peristomium typically consist of one dorsal and one to three ventral rings, merging into the upper and lower lips of the mouth. Unfortunately, detailed morphological descriptions of the peristomium have only been provided for a few species [23,36] (Figure 10C-E). The ventral mouth is connected to an axial proboscis, which is multilobed when everted and divided into proximal unciliated and distal ciliated zones [64]. The posterior part of peristomium possesses a pair of rounded ciliated areas of unknown function in Axiokebuita and Speleobregma, with potential taxonomic value (Figure 11F) [26].

The trunk includes up to 60 segments, each of them typically bearing one to six rows of elevated pads giving the worms an areolate appearance (Figures $9 \mathrm{C}$ and $10 \mathrm{~A}-\mathrm{C}$ ). The number of these rows, as well as the number and size of the pads that form each of them, varies across different species and body regions. The pattern formed by the pads has been used to diagnose certain species, suggesting that these patterns might be species-specific in some genera [36]. Epidermal papillae are absent in Scalibregmatidae. A midventral groove is present in most genera, extending from the mouth towards the pygidium along the longitudinal body axis (Figure 10A). It is not clear, though, whether this structure bears systematic information or if its appearance depends on the post mortem contraction of the trunk musculature [23]. Transverse bands of presumably motile cilia have been described on S. lanzaroteum and A. cavernicola [26] (Figure 10D,E).

Branchiae have been considered as an important taxonomic character. The presence of branchiae in the anterior segment characterizes the genera Scalibregma, Sclerobregma, Cryptosclerocheilus Blake, 1972, and Parasclerocheilus Fauvel, 1928 (Figure 9A), in which they are attached to the notopodium from segment 2 up to segment 5-7. Branchiae are arborescent in most species, branching dichotomously a variable number of times; but can also be pectinate, with individual branchial filaments arising from an elongate flattened lamella, as in Sclerobregma branchiatum Hartman, 1965 (Figure 9A) [23]. However, recent studies suggest that their number and arrangement might vary ontogenetically within the same species $[23,36]$. This has raised concerns about the validity of certain species identification, particularly when few small individuals have been studied, and growth series are not incorporated into species descriptions. More information on the ontogeny of other species of Scalibregmatidae can be found elsewhere $[23,26,36]$.

Parapodia are biramous in all scalibregmatids. The development of each ramus largely varies across species and body regions, but they are typically smaller anteriorly and more elongated towards the posterior body end. Parapodial structures, such as interramal papillae and parapodial cirri have been described in some species, holding useful taxonomic information. Interramal papillae are retractile and ciliated in S. inflatum [28] and Asclerocheilus (Figure 12B); whereas species of Oligobregma present interramal ciliated areas (Figure 12C). Interramal papillae in A. cavernicola and S. lanzaroteum project from the body wall and bear terminal ciliation [26,61] (Figure 12A,D). Nonciliated glandular papillae have been observed in S. minutus Grube, 1863 [41], and P. palmeri Blake, 2015 [36]. Parapodial dorsal and ventral cirri may help discriminating amongst species. Cirri are filiform in Axiokebuita and Speleobregma (Figure 9G), and leaf-shaped in Oligobregma, Pseudoscalibregma Ashworth, 1901, Scalibregma, and Sclerobregma. Cirri often exhibit glands, which are tubular in some species of Scalibregma, Oligobregma, and Pseudoscalibregma; but circular in Axiokebuita and Speleobregma. Parapodial lobes or lamellae are described in Asclerocheilus californicum and in the two species of the genus Scalibregmides (Figure 9F) [31,40].

The arrangement of chaetae is a very important taxonomic characteristic in Scalibregmatidae. Chaetae are always simple and might include long capillaries (Figure 10A), geniculated (Figure 12I), lyrate (Figure 12E,G), short spinous (Figure 12H), and acicular (Figure 12F,H). Simple capillary chaetae are present in all described species, while the presence or absence of other types of chaetae is an important character to diagnose genera. The absence of lyrate chaetae characterizes the genera Speleobregma and Axiokebuita, whereas the morphology of these chaetae is useful to diagnose species in genera such as Hyboscolex and Asclerocheilus, amongst others. Spinous chaetae are small and typically 
arranged as a single row restricted to the anterior most body segments. Since they occupy similar position to the lyrate chaetae, they are presumed as homologous to the former and rarely used in taxonomy. The presence of acicular chaetae, in contrast, is very useful and characterizes the genera Sclerobregma, Parasclerocheilus, Asclerocheilus, Sclerocheilus, and Oligobregma. Acicular chaetae are large and conspicuous, typically sickle-shaped or curved, and covered with fibrils visible in the scanning electron microscope. They are restricted to the anterior most segments and their arrangement is useful for species diagnoses. They can extend through a variable number of segments either on the notopodia or in both rami. Finally, geniculate chaetae are only found in S. lanzaroteum [124].

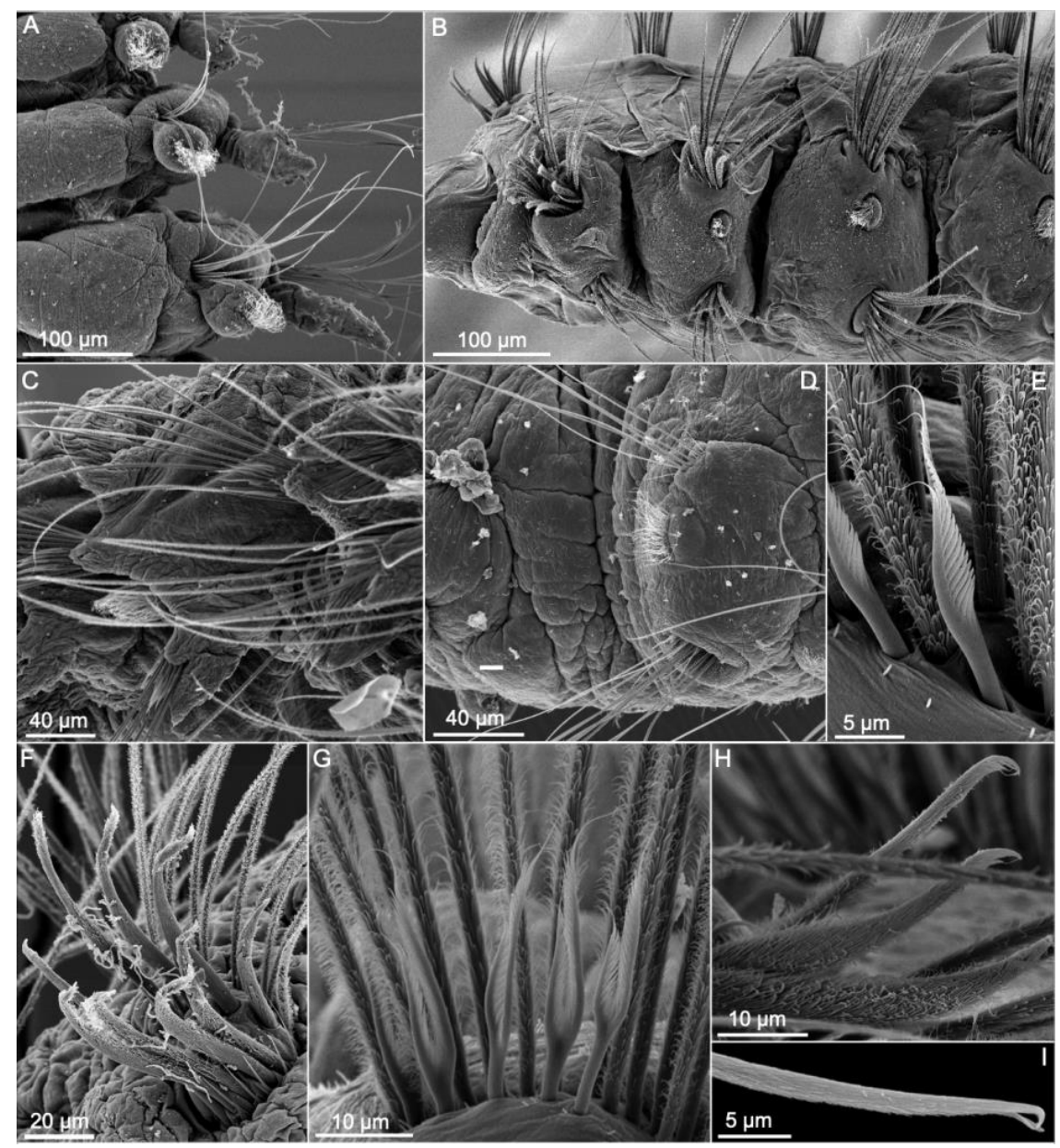

Figure 12. SEM micrographs of several Scalibregmatidae showing main diagnostic characters. (A) Speleobregma lanzaroteum, parapodia on the anterior segments in dorsal view, showing the presence of cirri; (B) Asclerocheilus sp., Canary Islands, parapodia on the anterior segments in lateral view; (C) Asclerocheilus sp., northwestern Spain, mid-body parapodium in frontal view; (D) Axiokebuita cavernicola, mid-body parapodium in frontal view; (E), Asclerocheilus sp., Canary Islands, lyrate chaetae on anterior segments in lateral view; (F) Asclerocheilus sp., northwestern Spain, spines on segment 1; (G) Asclerocheilus sp., Canary Islands, lyrate chaetae on mid-body segment; (H) Asclerocheilus sp., Canary Islands, spines; (I) S. lanzaroteum, geniculate chaetae.

The pygidium is quite variable across different scalibregmatids. However, since scalibregmatids are found lacking the posterior end in most samples, the usefulness of this character is limited. In most species, the pygidium is simple and bears a typically terminal anus and surrounded by a variable number of cirri (Figure 11G) whose arrangement, length, and number are potentially useful to identify species. Species of Axiokebuita and Speleobregma possess two enlarged rounded pygidial lobes covered with adhesive papillae (Figure 11H). 


\subsubsection{Internal Morphology}

The internal morphology of Scalibregmatidae was thoroughly investigated during the early 20th century, particularly in the species S. inflatum [28] and S. minutus [41] mostly based on histological sections. Unfortunately, after these early works, very few studies have been undertaken using more modern microscopical techniques.

The body wall consists of the epidermis, which comprises elongated columnar cells and mucous secreting cells, as well as a muscular layer of circular muscles surrounding dorsal and ventral longitudinal muscular bundles [28]. Narrow oblique muscles are also present, arising ventrally from each side of the nerve cord and inserting into the body wall near the notopodial chaetal sacs. Parapodial musculature is limited to the chaetal sacs as well as the parapodial retractor muscles [28]. There is also a relatively strong mouth and pharyngeal musculature, with retractor muscles attached to the proboscis and two short muscles supplying the nuchal organs [28].

A thin epithelium delineates the coelomic cavity, which is well developed and spacious. As an adaptation for burrowing, septa are reduced along most of the body [28,41]. The gut is linear and attaches to the body cavity by few strands of muscular tissue in S. inflatum. The esophagus is straight and covered with secretory glands; whereas the midgut is wider and curled, and the hindgut is short, linear, and opens directly into the anus. Several blood sinuses are associated with the stomach in S. inflatum and S. minutus [28,41].

There is also a well-developed vascular system [28,41], consisting of dorsal and ventral vessels and their derivatives. The dorsal vessel extends along the alimentary canal supplying it with capillary vessels. It forms a blood reservoir near the anterior end of the stomach and a conical heart-like bulb before branching off to supply the pharynx, the peristomium, and the brain. The ventral blood vessel originates near the mouth and continues posteriorly, extending dorsally along the nerve cord. In S. inflatum, it supplies the branchiae, the stomach, and nephridia, as well as the chaetal sacs and their adjacent tissues.

A pair of metanephridia occurs in each chaetigerous segments, except for those most anterior. Gonads are associated with each metanephridium and are formed by the proliferation of cells covering the septum by which the nephrostome is attached to the body wall [28]. The gametes are released from the gonad at an early stage and complete their maturation in the coelom. Male gonads form sperm platelets bearing spermatids in $S$. australis and O. mucronata, and they mature into ect-aquasperm [36].

The brain has an anterior lobe associated with the prostomium and two posterior lobes associated with the nuchal organs. The prostomial appendages are innervated by a pair of nerves originating from the anterior lobe of the brain, whereas the esophageal connectives and the nerves innervating the nuchal organs arise from the middle and posterior lobes, respectively. The palps are innervated by one ventral and one dorsal nerve, corresponding to the fourth and ninth pairs respectively [42].

\subsubsection{Species Diversity and Distribution}

The most species rich scalibregmatid genus is Asclerocheilus, with 14 described species, followed by Oligobregma (12 species), Hyboscolex Schmarda, 1861 (10 species), Pseudoscalibregma (eight species), Scalibregma (eight species) and Sclerocheilus (four species). The remaining genera are less diverse, including Polyphysia Quatrefages, 1866 (three species), Axiokebuita (two or three species depending on the sources), Parasclerocheilus (two species), Scalibregmides Hartmann-Schröder, 1965 (two species), and the monotypic Cryptosclerocheilus, Lipobranchius Cunningham and Ramage, 1888, Sclerobregma, and Speleobregma.

From a geographical point of view, scalibregmatids have been reported throughout the world and are present in all marine ecoregions [45] (Figure 7B). Most of the species have been described from the Temperate Northern Atlantic (17 species) and the Southern Ocean ecoregions (14 species), which together host nearly the half of the scalibregmatid type localities (Figure 7B). However, while the abundance of described species in the Temperate Northern Atlantic might just reflect the higher attention that historically has been paid to 
the fauna of this region, the presence of so many scalibregmatids in Antarctica is somehow unusual and might respond to unidentified ecological or historical processes. This is particularly remarkable given that nearly all Antarctic species seem to be endemic from that area, although this endemism might be exacerbated by the lack of studies in surrounding deep-sea areas. The remaining type localities are distributed across the Temperate Northern Pacific (nine species), Temperate Australasia (seven species), Tropical Atlantic (six species), Tropical Eastern Pacific, Temperate South America, Arctic, and Temperate Southern Africa (all with four species), Western Indo-Pacific (three species), and Central Indo-Pacific (two species). However, given the fragmentary information available on the family, this pattern most likely reflects the different attention that the group has received across the world than any other biological meaningful factors.

Many scalibregmatids seem to have relatively broad distribution ranges. A remarkable example is A. minuta, which has been recorded both in Arctic and Antarctic latitudes, as well as hydrothermal vents in the Pacific Ocean and in the Galician Bank, off Northwest Spain (but see [23]); or S. inflatum, recorded from Northern Europe as well as from South Africa [117], Australia [38], Chile [40], and Japan [121]. However, many of these records are exclusively based on morphological data often evaluated from few specimens, generally preserved in suboptimal conditions. Therefore, one might expect that more detailed morphological examinations and the inclusion of molecular data will reveal that these records actually correspond to complex of species with narrower distributions and betterdefined ecological preferences. For example, the re-examination of material originally attributed to $S$. inflatum has already revealed several different species with more restricted distribution. This includes the recent description of S. australis Blake, 2015 based on the detailed examination of growth series of Antarctic material [36], S. californicum Blake, 2000 from California [119], as well as S. celticum Mackie, 1991 and S. hanseni Bakken, Oug and Kongsrud, 2014 from Europe [34,35]. Remarkably, these last species show sympatric occurrence with $S$. inflatum. Such discoveries, even in the relatively well explored waters of Europe, highlight once again that our knowledge on the diversity of the Scalibregmatidae is still very limited. Therefore, most discussions on the distribution patterns of the scalibregmatid species remain speculative.

In contrast to those species with large distribution areas, other species are exclusively known from a few localities. This is the case of the species Scalibregmides chilensis Hartmann-Schröder, 1965, recorded only once from Puerto Aguirre (Chile) [40] and S. peruanus Blake, 1981 from Callao (Peru) [31]; a few species of the genus Oligobregma, such as O. whaleyi Wiklund, Neal, Glover, Drennan, Rabone and Dahlgren, 2019 from a single deep-sea locality in the Pacific [2], or O. oculata Kudenov and Blake, 1978 and O. simplex Kudenov and Blake, 1978 each known from a single locality around Victoria (Australia) [38]. However, once again, the actual endemic status of these species remains doubtful due to our limited knowledge.

The endemism of S. lanzaroteum and A. cavernicola deserves a separate comment since the species are restricted to two different volcanic lava tubes in the Canary Islands [26]. Speleobregma lanzaroteum is an elusive species exclusively known from La Corona lava tube, in Lanzarote, an anchialine cave penetrating the saline aquifer of the island and characterised by the presence of a highly distinct fauna [125]. The species was described based on a single specimen collected in 1981 and only observed again after 27 years, when two more individuals were recovered in two successive dives [26,125]. The fact that these are the only three records of the species is remarkable because the cave has been regularly sampled over the last 40 years by well-trained cave divers who were explicitly sampling the fauna [126-129]. Therefore, the scarcity of records for Speleobregma lanzaroteum is more likely attributed to the low population densities described for many other cave species, than to an actual lack of sampling efforts [130]. Axiokebuita cavernicola is, in contrast, limited to a specific gravelly patch found in Los Cerebros cave in Tenerife [26], while it is absent in the muddy or sandy sediments found elsewhere in the cave [131]. The fact that 
both species are found in specific areas inside caves supports the idea that they may be actually endemic from these cave localities [132].

\subsubsection{Biology and Ecology}

Most scalibregmatids prefer muddy sediments at depths greater than $100 \mathrm{~m}$. This seems to be the case, at least, for species in the genus Scalibregma, Oligobregma, Polyphysia, Lipobranchius, and Pseudoscalibregma, which are considered subsurface deposit feeders capturing food particles with their eversible multilobulated proboscis [85]. In particular, S. inflatum and S. californicum burrow by pushing the sediment to the sides of the body by lateral movements of the prostomium and afterwards moving forward by producing peristaltic waves [133]. The presence of the prostomial appendages probably increases the efficiency of this so-called shoveling process, while the absence of septa makes the production of waves more efficient. Polyphysia crassa (Örsted, 1843) burrows in a similar way, lacking prostomial horn, but also possessing reduced septa and a glandular epidermis to increase the efficiency of the peristaltic movements $[85,134,135]$. Because of the burrowing behavior, scalibregmatids play an important ecological role in soft bottoms bringing burrowed particles near to the surface, as it has been showed in the Cape Hatteras area [136] where they can be present quite deep in the sediment column [137]. These burrowing species can become very abundant or even dominate the benthic communities, as it has been shown for S. australis at the east side of the Antarctic Peninsula [36], and S. inflatum in Cape Hatteras between 550-1500 m depth [138]. Indirect evidence from various sources suggests that these are not isolated cases, but rather that species of these scalibregmatid genera might dominate soft bottom assemblages in many areas in high latitudes [23,35].

However, there are other species of scalibregmatids that seem to exhibit different habitat preferences. For example, Oligobregma brasirae Wiklund, Neal, Glover, Drennan, Rabone and Dahlgren, 2019, O. whaleyi, and O. tanyi Wiklund, Neal, Glover, Drennan, Rabone and Dahlgren, 2019, are exclusively known from the polymetallic nodule exploration areas in the eastern Clarion-Clipperton Zone [2], and there are many records of species of Axiokebuita from gravel, deep Desmophyllum Ehrenberg, 1834 coral reefs [26,61,103], or even rock crevices near hydrothermal vents at the Pacific Antarctic Ridge [139]. In shallow waters scalibregmatids are not uncommon in hard substrates. For example, Scalibregmides chilensis has been recorded from a mytilid bank [40], Hyboscolex quadricincta Kudenov, 1985, Asclerocheilus tropicus Blake, 1981, and A. mexicanus Kudenov, 1985 have been collected from dead corals and sponges [25,39]; Asclerocheilus acirratus (Hartman, 1966) and Hyboscolex verrucosa Hartmann-Schröder, 1979 are known from algae in hard substrates [140,141], and Asclerocheilus kudenovi Blake, 2000 and H. oculatus (Ehlers, 1901) are recorded from unspecified hard, rocky substrates [119,142]. Axiokebuita cavernicola has only been reported from gravel sediments in the middle section of Los Cerebros lava tube in Tenerife, where there is an active water movement produced by waves driving a notable input of organic matter into the gravelly bed [26]. Adults of this species attach to the gravel particles using the adhesive papillae of the pygidium, while they collect suspended food particles using the water currents produced by the ciliation on their palps. Upon perturbation, they can also swim short distances using undulatory movements of the trunk. In contrast, juveniles of $A$. cavernicola lack palps and adhesive pygidium, and usually are found actively crawling and ciliary swimming in the petri dishes [26]. In contrast, S. lanzaroteum lives in La Corona lava tube, an anchialine cave system where food is limited to the organic matter carried by tidal currents [143]. Remarkably, S. lanzaroteum has only been found swimming in the water column using undulatory body movements and gentle movement of the parapodia. Similar life strategies have been discovered in other annelids exclusively reported in their isolated cave systems $[126,144,145]$, suggesting that drifting in the water column might be the optimal life strategy in these type of cave environments. The capability of swimming is not unique in this cave-adapted scalibregmatid, since adults of several typically benthic species, such as $S$. 
inflatum and L. jeffreysii (McIntosh, 1869) have been occasionally reported swarming in the plankton [146-148], although in all these cases, individuals possess specialized swimming chaetae.

The reproduction of scalibregmatids is largely unknown, and detailed studies are only available for a few selected species $[23,149]$. Fertilization is unknown but spawning might take place in the water column. This is presumed given the presence of ect-sperm and large oocytes in many species, as well as the observation of adult individuals of $S$. inflatum, L. jeffreysii and possibly S. celticum, swimming in the water column of the ocean, sometimes provided with long natatory chaetae [34,146-148]. Finally, despite nothing is known about the embryonic development, we known the postembryonic development of $S$. australis, O. mucronata and A. cavernicola $[26,36]$ from the description of series of individuals of different size.

\section{Conclusions and Future Perspectives}

The Opheliidae are well known in some parts of the world such as the northern Atlantic; some areas (e.g., Pacific, Atlantic Africa), however, remain clearly understudied. The status of cosmopolitan species and several species not reported after original description should be reassessed. Furthermore, proper evaluation of some taxonomic characters needs to consider ontogenetic variability and preservation artefacts. Regarding Scalibregmatidae, the knowledge of the species richness and distribution is often fragmentary and strongly biased by the unbalanced sampling effort across the world. Indeed, except for the Antarctic and the northwestern Atlantic, the remaining marine areas have been poorly studied when it comes to Scalibregmatidae. Furthermore, both the position of this family within Annelida as well as its internal evolutionary relationships and systematics remain unresolved, warranting further assessment combining different sources of data; this also applies to Opheliidae because a full phylogenetic analysis of this family is still lacking as well.

Finally, as it still happens with other annelid families, current knowledge on the internal anatomy, life cycles, ecology, and behavior of opheliids and scalibregmatids has been obtained from a few studies on some common species. In this sense, traditional taxonomic approaches coupled with modern microscopy imaging techniques (e.g., microCT, SEM) and molecular methods (e.g., molecular phylogenies and species delimitation analyses) are needed; this will be paramount to assess properly intraspecific diversity issues that have hampered the taxonomy of these families in the past. This may be especially useful in finding appropriate, robust characters with systematic value in these morphologically homogenous taxa, aiding in an effective assessment of their current species diversity, and, ultimately, their distribution patterns and ecological preferences.

Author Contributions: Conceptualization and supervision, J.P., A.M. and J.M.; methodology, investigation, writing —original draft preparation, review and editing —and illustrations J.P., A.M. and J.M.; and funding acquisition, J.P. All authors have read and agreed to the published version of the manuscript.

Funding: This research has been partially funded by FAUNA IBÉRICA research project Polychaeta VII, Palpata, Canalipalpata II (PGC2018-095851-B-C64) sponsored by the Agencia Estatal de Investigación and coordinated by JP. Pat Hutchings (Australian Museum) which has also provided some funds to cover the publication costs.

Acknowledgments: Authors would like to thank Ada Castro and Catalina Sueiro (Servizos de Apoio á Investigación, Universidade da Coruña) for SEM assistance, to María Candás (Estación de Bioloxía Mariña da Graña-Ferrol, Universidade de Santiago de Compostela, Spain) for assistance with the micro-CT and to Antón Taboada for line drawings. We are also grateful to Jorge Núñez for sharing with us the material of Pseudoscalibregma sp. from the Canary Islands. Authors deeply thank reviewers' comments on the manuscript and Maria Bogomolova for language revision.

Conflicts of Interest: The authors declare no conflict of interest. 


\section{Appendix A}

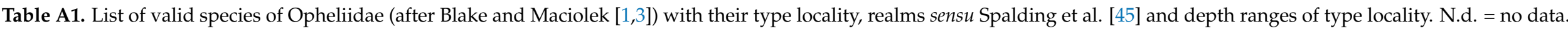

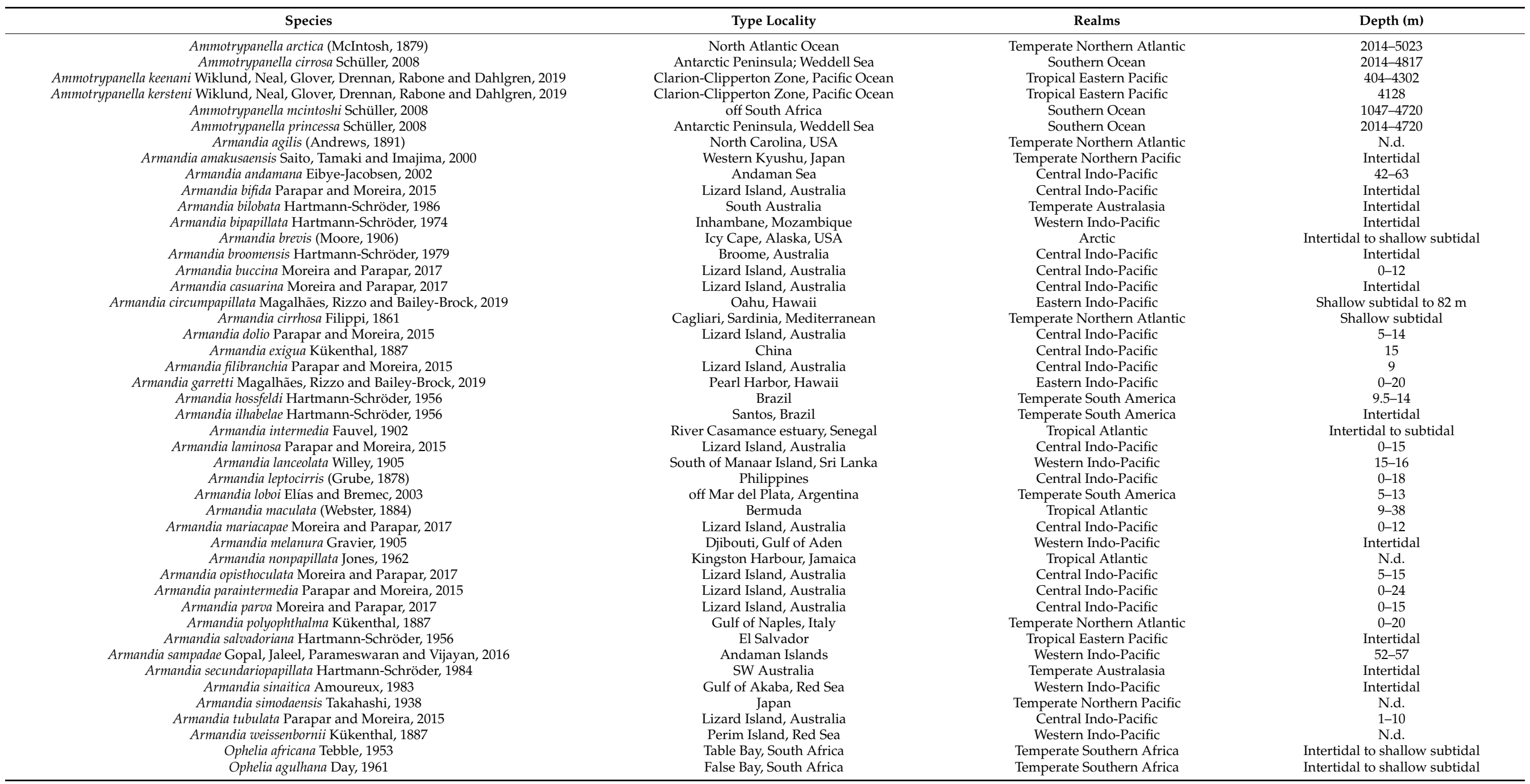


Table A1. Cont.

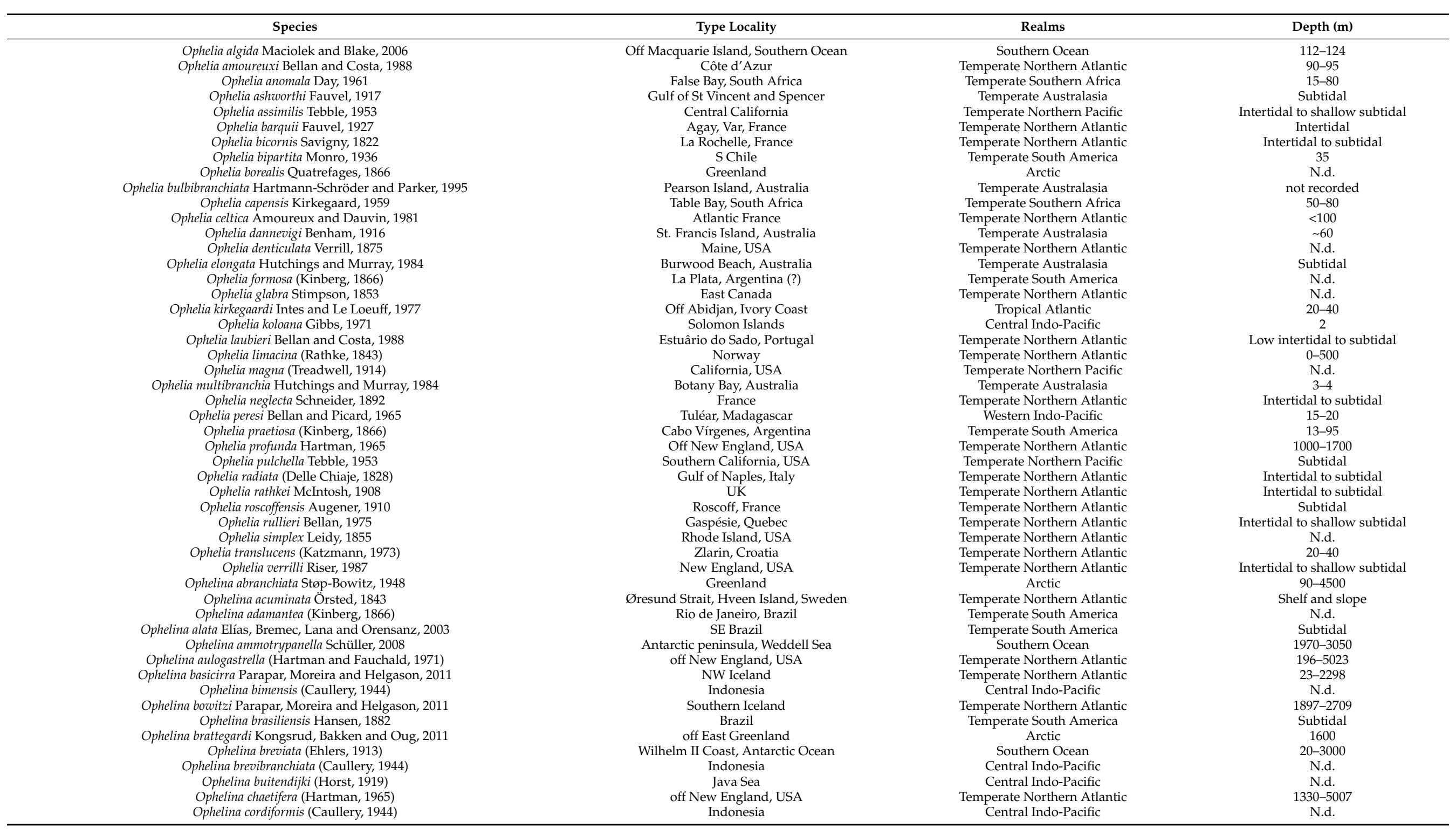


Table A1. Cont.

\section{Species}

Ophelina curli Wiklund, Neal, Glover, Drennan, Rabone and Dahlgren, 2019 Ophelina cylindricaudata (Hansen, 1879)

phelina cyprophilia Neave and Glasby, 2013 Ophelina delapidans (Kinberg, 1866) Ophelina dubia (Caullery, 1944) Ophelina ehlersi (Horst, 1919)

Ophelina ganae Wiklund, Neal, Glover, Drennan, Rabone and Dahlgren, 2019 Ophelina gaucha Elías, Bremec, Lana and Orensanz, 2003

Ophelina hachaensis Augener, 1934 Ophelina helgolandiae Augener, 1912 Ophelina gigantea (Rullier, 1965) Ophelina grandis (Pillai, 1961) Ophelina groenlandica Støp-Bowitz, 1948 Ophelina gymnopyge (Ehlers, 1908)

Ophelina jeffreysi (McIntosh in Jeffreys, 1876

Ophelina juhazi Wiklund, Neal, Glover, Drennan, Rabone and Dahlgren, 2019 Ophelina kampeni (Horst, 1919)
Ophelina kinbergii Hansen, 1882

Ophelina kohni Magalhães, Rizzo and Bailey-Brock, 2019

Ophelina kuekenthali (McIntosh, 1908)

Ophelina langii (Kükenthal, 1887)

Ophelina longicephala Hartmann-Schröder, 1977

Ophelina longicirrata Hartmann-Schröder and Parker, 1995

Ophelina manana Magalhães, Rizzo and Bailey-Brock, 2019
Ophelina martinezarbizui Wiklund, Neal, Glover, Drennan, Rabone and Dahlgren, 2019

Ophelina meyerae Wiklund, Neal, Glover, Drennan, Rabone and Dahlgren, 2019

Ophelina minima Hartmann-Schröder, 1974

Ophelina modesta Støp-Bowitz, 1958 Ophelina nematoides (Ehlers, 1913)

Ophelina nunnallyi Wiklund, Neal, Glover, Drennan, Rabone and Dahlgren, 2019 Ophelina nybelini (Eliason, 1951)

Ophelina opisthobranchiata Wirén, 190

Ophelina profunda (Caullery, 1944)

Ophelina pygocirrata (Ehlers, 1920)

Ophelina remigera (Ehlers, 1918)

Ophelina robusta Schüller, 2008

Ophelina scaphigera (Ehlers, 1900)

Ophelina setigera (Hartman, 1978)

Ophelina sibogae (Caullery, 1944)

Ophelina syringopyge (Ehlers, 1901)

Polyophthalmus a tralis Grube, 1869

Polyophthalmus ceylonensis Küke, 1869

Polyophthalmus collaris Michaelsen, 1892

Polyophthalmus longisetosus Michaelsen, 1892

Polyophthalmus mauliola Magalhães, Rizzo and Bailey-Brock, 2019 Polyophthalmus pictus (Dujardin, 1839)

\section{Type Locality}

Clarion-Clipperton Zone, Pacific Ocean

off West Norway

Darwin Harbour, Australia

Valparaiso, Chile

Indonesia

Jedan, Aroe Isles, Indonesia

Clarion-Clipperton Zone, Pacific Ocean SE Brazil

Riohacha, Colombia

Spitsbergen, Norway

Spitsbergen, Norway

Tambalagam Bay, Sri Lanka East Greenland

Kerguelen Islands
Labrador Sea, North Atlantic Ocean

Clarion-Clipperton Zone, Pacific Ocean

Jedan, Aroe Isles, Indonesia

Río de Janeiro, Brazil

Guam

orth Atlantic Ocea

Philippines

Indonesia

Off Portugal

South Australia

Clarion-Clipperton Zone, Pacific Ocean

Clarion-Clipperton Zone, Pacific Ocean

$$
\begin{aligned}
& \text { Skagerrak } \\
& \text { Oslo, Norway }
\end{aligned}
$$

Oslo, Norway

East Norway

Clarion-Clipperton Zone, Pacific Ocean Azores Islands Spitsbergen, Norway

$$
\begin{aligned}
& \text { Indonesia } \\
& \text { Indonesia }
\end{aligned}
$$

Aru Islands, Sungi Manumbai, Indonesi Antarctic Peninsula, Weddell Sea Magellan Strait

$$
\text { Java }
$$

South Georgia

Melville Bay, Australia

Cri Lanka
Sri

Sri Lanka

amala Bay, Hawa

France

Qingdao, Yellow Sea

\section{Realms}

Tropical Eastern Pacific

Temperate Northern Atlan

Central Indo-Pacific

Temperate South Americ

Central Indo-Pacific

Central Indo-Pacific

Tropical Eastern Pacific

Temperate South America

Tropical Atlantic$$
\text { Arctic }
$$

Temperate Australasia

Western Indo-Pacific

Arctic

Arctic

Tropical Eastern Pacific

Central Indo-Pacific

Cemperate South America

Central Indo-Pacific

Temperate Northern Atlantic

Central Indo-Pacific

Central Indo-Pacific

Temperate Northern Atlantic

Temperate Australasia

Eastern Indo-Pacific

Tropical Eastern Pacific

mperate Northern Atlantic

Northern Atlantic

$$
\text { Southern Ocean }
$$

Temperate Northern Atlantic

Tropical Eastern Pacific

emperate Northern Atlantic$$
\text { Arctic }
$$

Central Indo-Pacific

Central Indo-Pacific

Central Indo-Pacific

Southern Ocean

Temperate South America

Southern Ocean

Central Indo-Pacific

Southern Ocean

Central Indo-Pacific

Central ndo-Pacicic

Western Indo-Pacific

Western Indo-Pacific

Eastern Indo-Pacific

Temperate Northern Atlantic

Temperate Northern Pacific
Depth (m)

4026

$7-4663$

Shallow subtidal

N.d.

N.d.

4076-4302

6
$562-2710$
$2 . d$.

N.d.

Shelf and slope

13-199

$1066-3200$
4100

4100

Subtidal

Shallow subtida

$\sim 1400$

20

N.d.
77

N.d.

400-500

(3)

230-645

100-200

246-2725

Subtidal

$4425-4302$

$4540-4600$

800-3900

N.d.

N.d.

2668-3050

18-3382

3111
$79-81$

保

N.d.

N.d.

N.d.

Intertidal 
Table A1. Cont.

\begin{tabular}{|c|c|c|c|}
\hline Species & Type Locality & Realms & Depth (m) \\
\hline Polyophthalmus striatus Kükenthal, 1887 & Hong Kong & Central Indo-Pacific & N.d. \\
\hline Polyophthalmus translucens Hartman, 1960 & Southern California, USA & Temperate Northern Pacific & 914 \\
\hline Thoracophelia arctica (Grube, 1866) & Arctic Ocean & Arctic & N.d. \\
\hline Thoracophelia bibrancha (Hutchings and Murray, 1984) & Merimbula, Australia & Temperate Australasia & Intertidal \\
\hline Thoracophelia dillonensis (Hartman, 1938) & Dillon Beach, California, USA & Temperate Northern Pacific & Intertidal \\
\hline Thoracophelia ezoensis Okuda, 1936 & Hokkaido, Japan & Temperate Northern Pacific & N.d. \\
\hline Thoracophelia flabellifera Ziegelmeier, 1955 & German Bight, North Sea & Temperate Northern Atlantic & 13 \\
\hline Thoracophelia furcifera Ehlers, 1897 & Punta Arenas, Magellan Strait & Temperate South America & Intertidal \\
\hline Thoracophelia heterocirra (Rozbaczylo and Zamorano, 1970) & El Tabo, Chile & Temperate South America & Intertidal \\
\hline Thoracophelia japonica (Misaka and Sato, 2003) & Oura Bay, Japan & Temperate Northern Pacific & $0-16$ \\
\hline Thoracophelia longiseta (Hutchings and Murray, 1984) & Ocean Beach, Australia & Temperate Australasia & Intertidal \\
\hline Thoracophelia mucronata (Treadwell, 1914) & La Jolla, Southern California & Temperate Northern Pacific & Intertidal \\
\hline Thoracophelia otagoensis (Probert, 1976) & Otago Peninsula, New Zealand & Temperate Australasia & Intertidal \\
\hline Thoracophelia papillata (Santos, Nonato and Petersen, 2004) & Abaís beach, Brazil & Tropical Atlantic & Intertidal \\
\hline Thoracophelia profunda (Hartman, 1967) & Cape Horn, Chile & Temperate South America & 4008 \\
\hline Thoracophelia yasudai Okuda, 1934 & Kainawa, Japan & Temperate Northern Pacific & Intertidal \\
\hline Thoracophelia williamsi (Hartman, 1938) & Dillon Beach, California, USA & Temperate Northern Pacific & Intertidal \\
\hline Thoracophelia zeidleri (Hartmann-Schröder and Parker, 1995) & Haystack Beach, Australia & Temperate Australasia & Intertidal \\
\hline
\end{tabular}

Table A2. List of valid species of Scalibregmatidae (after Blake [3,23]) with their type locality, realms sensu Spalding et al. [45] and depth ranges of type locality. N.d. = no data.

\begin{tabular}{|c|c|c|c|}
\hline Species & Type Locality & Realms & Depth (m) \\
\hline Asclerocheilus acirratus (Hartman, 1966) & White Cove, Southern California, USA & Temperate Northern Pacific & $0-3$ \\
\hline Asclerocheilus ashworthi Blake, 1981 & Elephant Island, Antarctica & Southern Ocean & $223-397$ \\
\hline Asclerocheilus beringianus Uschakov, 1955 & Bering Sea & Arctic & 986-2005 \\
\hline Asclerocheilus californicus Hartman, 1963 & Santa Monica, Redondo and San Pedro valley, California, USA & Temperate Northern Pacific & $542-890$ \\
\hline Asclerocheilus capensis Day, 1963 & South Africa & Temperate Southern Africa & $9-26$ \\
\hline Asclerocheilus elisabethae Eibye-Jacobsen, 2002 & Thailand, Andaman Sea & Western Indo-Pacific & $70-76$ \\
\hline Asclerocheilus glabrus (Ehlers, 1887) & Cuba & Tropical Atlantic & 320 \\
\hline Asclerocheilus intermedius (Saint-Joseph, 1894) & Dinard, France & Temperate Northern Atlantic & 96-1830 \\
\hline Asclerocheilus kudenovi Blake, 2000 & Point Arguello, California, USA & Temperate Northern Pacific & $91.5-123$ \\
\hline Asclerocheilus mexicanus Kudenov, 1985 & Florida, Gulf of Mexico & Tropical Atlantic & $2.4-76.2$ \\
\hline Asclerocheilus shanei Hartmann-Schröder, 1994 & Scamander, Tasmania & Temperate Australia & 122 \\
\hline Asclerocheilus shanonae Eibye-Jacobsen, 2002 & Thailand, Andaman Sea & Western Indo-Pacific & $70-76$ \\
\hline Asclerocheilus tasmanicus Kirkegaard, 1996 & Tasman Sea, W of New Zealand & Temperate Australia & $3710-3830$ \\
\hline Asclerocheilus tropicus Blake, 1981 & NW off Guayaquil, Ecuador & Tropical Eastern Pacific & 3-10 \\
\hline Asclerocheilus victoriensis Blake, 2000 & Victoria, Australia & Temperate Australia & $6-22$ \\
\hline Axiokebuita cavernicola Martínez, Di Domenico and Worsaae, 2013 & Los Cerebros cave, Tenerife, Canary Islands & Temperate Northern Atlantic & $8-15$ \\
\hline Axiokebuita minuta (Hartman, 1967) & Antarctica & Southern Ocean & 180-3685 \\
\hline Cryptosclerocheilus baffinensis Blake, 1972 & Southern Baffin Bay & Arctic & 1830 \\
\hline Hyboscolex dicranochaetus (Schmarda, 1861) & Table Bay, Cape New Hope, South Africa & Temperate Southern Africa & $0.5-19.8$ \\
\hline Hyboscolex equatorialis Blake, 1981 & NW of Guayaquil, Ecuador & Temperate Southern America & $8-9$ \\
\hline Hyboscolex homochaetus (Schmarda, 1861) & New Zealand & Temperate Southern Africa & N.d. \\
\hline Hyboscolex longisetus Schmarda, 1861 & Table Bay, Cape New Hope, South Africa & Temperate Southern Africa & $9-110$ \\
\hline
\end{tabular}


Table A2. Cont.

Species

Hyboscolex oculatus (Ehlers, 1901) Hyboscolex pacificus (Moore, 1909) Hyboscolex quadricincta Kudenov, 1985
Hyboscolex reticulatus (McIntosh, 1885) Hyboscolex reticulatus (McIntosh, 1885$)$
yboscolex verrucosus Hartmann-Schröder, 1979 Lipobranchius jeffreysii McIntosh, 1869 Orobregma aciculatum (Hartman, 1965)

Oligobregma brasierae Wiklund, Oligobregma collare (Levenstein, 1975)

Oligobregma mucronata Blake, 2015 Oligobregma mucronata Blake, 201

Oligobregma oculata Kudenov and Blake, 1978

Oligobregma pseudocollare Schüller and Hilbig, 2007

Oligobregma quadrispinosa Schüller and Hilbi, 2007

Oligobregma tani Wiklund, Neal, Glover, Drennan, Rabone and Dahlgren, 2019

ne and Dahlgren, 2019

Parasclerocheilus branchiatus Fauvel, 1928

Parasclerocheilus capensis Day, 1961

Polyphysia caulleryi (McIntosh, 1922)

Polyphysia crassa (Örsted, 1843)

Polyphysia hystricis (McIntosh, 1922)

Pseudoscalibregma bransfieldium (Hartman, 1967)

Pseudoscalibregma hartmanae Blake, 1981

Pseudoscalibregma ortentalis Imajima, 2009

Pseudoscalibregma palmeri Blake, 2015

Pseudoscalibregma papilin Schüller, 2008

Pseudoscalibregma parzum (Hansen, 1878)

Pseudoscalibregma usarpium Blake, 1981

Scalibregma australis Blake, 2015

Scalibregma californicum Blake, 2000

Scalibregma celticum Mackie, 1991

Scalibregma hanseni Bakken, Oug and Kongsrud, 2014 Scalibregma inflatum Rathke, 1843 Scalibregma robustum Zachs, 1925

Scalibregma stenocerum (Bertelsen and Weston, 1980) Scalibregma wireni Furreg, 1925

Scalibregmella antennata Hartman and Fauchald, 1971

Scalibregmides chilensis Hartmann-Schröder, 196 Scalibregmides peruanus Blake, 1981 Sclerobregma branchiatum Hartman, 1965 Sclerocheilus antarcticus Ashworth, 1915
Sclerocheilus deriugini Sclerocheilus minutus Zachs, 1925 Sclerocheilus unoculus Kudenov, 1985 Speleobregma lanzaroteum Bertelsen, 1986

\section{Type Locality}

Tumbes Peninsula, near Talcahuano, Chile

Santa Monica, California, USA

Florida, Gulf of Mexico

Queen Charlotte Sound, New Zealand

Port Hedland, Western Australia

$$
\text { New England, abyssal }
$$

Clarion-Clipperton Zone, Pacific Ocean

Drake Passage, Antarctica

Greenpeace Trough, East Antarctic Peninsul

Palmer Archipelago, Antarctic Peninsula

East of Saint Maurice island, New Caledonia Scotia Sea, Antarctica

Western Port, Victoria, Australia

Clarion-Clipperton Zone, Pacific Ocean

Clarion-Clipperton Zone, Pacific Ocean

Shingle Island, Gulf of Manaar, India

angebaan Lagoon, South Afric

hannel slope, Antarctic

E. Bransfield Strait, Antarctica$$
\text { Japan }
$$

Kermapan

Weddell Sea Off Lindenberg Island, Antarctica South Sandwich Islands, Antarctica

$$
\text { North Sea }
$$

Ross Sea Antarctica

Greenpeace Trough, East Antarctic Peninsula Santa Maria Basin, off Point Sal, Californi Milford Haven, Dyfed, Wales

Egga, west of Nordland County, Norway Norway

White Sea, Russia

Daytona Beach, Florida

Kaiser Joseph Fjord, East Greenland

Bermuda, abyssal

island near Pucusana, south of Callao, Peru New England

Petermann Island, Antarctica

Korizine Mali Losinj, Croatia

Florida, Gulf of Mexico

La Corona lava tube, Lanzarote, Canary Islands

\section{Realm}

Depth $(\mathrm{m})$

Temperate Southern Americ

Trote Northern Pacific

Cemperate Australia

Temperate Northern Atlantic

Tropate Northern Atlantic

Southern Ocean

Temperate Northern Atlantic

Southern Ocean

Central Indo-Pacific

Southern Ocean

Southern Ocean

Temperate Australia

Tropical Eastern Pacific

Tropical Eastern Pacific

Western Indo-Pacific

Temperate Southern Africa

Temperate Northern Pacific

Temperate Northern Atlantic

emperate Northern Atlan Southern Ocean

Temperate Northern Pacific

emperate Australia

Southern Ocean

Temperate Northern Atlantic

Southern Ocean

Temperate Northern Pacific

Temperate Northern Atlantic

Temperate Northern Atlantic

Temperate Nothern Atlantic

$$
\text { Artic }
$$

Tropical Atlantic

Artic
Temperate Northern Atlantic

Temperate Southern Americ

Temperate Southern America Southern Ocean
Soute Northern Alt

Temperate Northern Pacific

$$
\text { Tropical Atlantic }
$$

Temperate Northern Atlantic ca. $0.5-10$

200

2011

$0-5$

$22-1194$
$1925-4825$

4425

3733-3806

$323-912$

57

$2889-2892$
$2258-2313$

11

4137

4425

26
47

0-1755

4701261

323-916

585

373-1005

$828-917$

385-768

53-1802

2143

12-978

12-978

$6-21$
765

1-3690

N.d.

3-9

4833-5023 


\section{References}

1. Blake, J.A.; Maciolek, N.J. 7.6.1 Opheliidae Malmgren, 1867. In Handbook of Zoology. Annelida: Pleistoannelida, Sedentaria II Schmidt-Rhaesa, A., Ed.; De Gruyter: Berlin, Germany, 2020.

2. Wiklund, H.; Neal, L.; Glover, A.G.; Drennan, R.; Rabone, M.; Dahlgren, T.G. Abyssal fauna of polymetallic nodule exploration areas, eastern Clarion-Clipperton Zone, central Pacific Ocean: Annelida: Capitellidae, Opheliidae, Scalibregmatidae, and Travisiidae. Zookeys 2019, 883, 1-82. [CrossRef]

3. WoRMS Editorial Board. Register of Marine Species. 2020. Available online: http://www.marinespecies.org/ (accessed on 15 February 2021).

4. Parapar, J. Familia Opheliidae. In Fauna Ibérica-Annelida Polychaeta III; Parapar, J., Alós, C., Núñez, J., Moreira, J., López, E. Aguirrezabalaga, F., Besteiro, C., Martínez, A., Ramos, M.A., Eds.; Museo Nacional de Ciencias Naturales, CSIC: Madrid, Spain, 2012; Volume 36, pp. 284-332.

5. Wilson, D.P. The Larval Development of Ophelia bicornis Savigny. J. Mar. Biol. Assoc. UK 1948, 27, 540-553. [CrossRef]

6. Dales, R.P. The larval development and ecology of Thoracophelia mucronata (Treadwell). Biol. Bull. 1952, 102, 232-242. [CrossRef]

7. Seike, K. Burrowing behaviour inferred from feeding traces of the opheliid polychaete Euzonus sp. as response to beach morphodynamics. Mar. Biol. 2008, 53, 1199-1206. [CrossRef]

8. Otegui, M.P.B.; Blankensteyn, A.; Pagliosa, P.R. Population structure, growth and production of Thoracophelia furcifera (Polychaeta: Opheliidae) on a sandy beach in Southern Brazil. Helgol. Mar. Res. 2012, 66, 479-488. [CrossRef]

9. Dorgan, K.M. Kinematics of burrowing by peristalsis in granular sands. J. Exp. Biol. 2018, 221, jeb167759. [CrossRef] [PubMed]

10. Giangrande, A.; Gambino, I.; Tundo, M.; Pasqua, M.; Licciano, M.; Fanini, L.; Pinna, M. Reproductive biology of Ophelia barquii (Annelida, Opheliidae) along the Salento Peninsula (Mediterranean Sea, South Italy). Mar. Biodiv. 2020, 50, 3. [CrossRef]

11. Meador, J.P.; Rice, C.A. Impaired growth in the polychaete Armandia brevis exposed to tributyltin in sediment. Mar. Environ. Res. 2001, 51, 113-129. [CrossRef]

12. Bat, L.; Şahin, F.; Öztekin, A. Acute toxicity of cadmium on Ophelia bicornis Savigny, 1822. Acta Aquat. Turc. 2019, 15, 289-297. [CrossRef]

13. Vanreusel, A.; Cosson-Sarradin, N.; Gooday, A.J.; Paterson, G.L.J.; Galéron, J.; Sibuet, M.; Vincx, M. Evidence for episodic recruitment in a small opheliid polychaete species from the abyssal NE Atlantic. Prog. Oceanogr. 2001, 50, 285-301. [CrossRef]

14. Kongsrud, J.A.; Bakken, T.; Oug, E. Deep-water species of the genus Ophelina (Annelida, Opheliidae) in the Nordic Seas, with the description of Ophelina brattegardi sp. nov. Ital. J. Zool. 2011, 78, 95-111. [CrossRef]

15. Parapar, J.; Moreira, J.; Helgason, G. Distribution and diversity of Opheliidae (Annelida, Polychaeta) on the continental shelf and slope of Iceland, with a review of the genus Ophelina in Northeast Atlantic waters and description of two new species. Org. Divers. Evol. 2011, 11, 83-105. [CrossRef]

16. Brown, R.S. The anatomy of the polychaete Ophelia cluthensis McGuire 1935. Proc. R. Soc. Edinb. 1938, 58, 135-160. [CrossRef]

17. McConnaughey, B.H.; Fox, D.L. The Anatomy and Biology of the Marine Polychaete Thoracophelia mucronata (Treadwell) Opheliidae. Univ. Calif. Publ. Zool. 1949, 47, 319-340.

18. Hermans, C.O.; Cloney, R.A. Fine structure of the prostomial eyes of Armandia brevis (Polychaeta: Opheliidae). Z. Zellforsch Mikrosk. Anat. 1966, 72, 583-596. [CrossRef] [PubMed]

19. Purschke, G.; Ding, Z.; Müller, M.C. Ultrastructural differences as a taxonomic marker: The segmental ocelli of Polyophthalmus pictus and Polyophthalmus qingdaoensis sp. n. Polychaeta, Opheliidae). Zoomorphology 1995, 115, 229-241. [CrossRef]

20. Tzetlin, A.B.; Filippova, A.V. Muscular system in polychaetes (Annelida). Hydrobiologia 2005, 535, 113-126. [CrossRef]

21. Law, C.J.; Dorgan, K.M.; Rouse, G.W. Relating divergence in polychaete musculature to different burrowing behaviors: A study using Opheliidae. J. Morphol. 2014, 275, 548-571. [CrossRef] [PubMed]

22. Misaka, T.; Sato, M. A new species of Euzonus (Polychaeta: Opheliidae) from subtidal zones in Japan. Zool. Sci. 2003, 20, 1171-1177. [CrossRef]

23. Blake, J.A. 7.6.3 Scalibregmatidae Malmgren, 1867. In Handbook of Zoology. Annelida: Pleistoannelida, Sedentaria II; Schmidt-Rhaesa, A., Ed.; De Gruyter: Berlin, Germany, 2020.

24. Rouse, G.W.; Pleijel, F. Polychaetes; Oxford University Press: Oxford, UK, 2001.

25. Kudenov, J.D. Four new species of Scalibregmatidae (Polychaeta) from the Gulf of Mexico, with comments on the familial placement of Mucibregma Fauchald and Hancock, 1981. Proc. Biol. Soc. Wash. 1985, 98, 332-340.

26. Martínez, A.; Di Domenico, M.; Worsaae, K. Evolution of cave Axiokebuita and Speleobregma (Scalibregmatidae, Annelida). Zool. Scr. 2013, 42, 623-636. [CrossRef]

27. Hartman, O.; Fauchald, K. Deep-water benthic polychaetous annelids off New England to Bermuda and other North Atlantic areas. Part II. Allan Hancock Monogr. Mar. Biol. 1971, 6, 1-327.

28. Ashworth, J.H. Memoirs: The Anatomy of Scalibregma inflatum, Rathke. J. Cell Sci. 1901, 45, 237-309.

29. Ashworth, J.H. On a New Species of Sclerocheilus, with a revision of the genus. Trans. R. Soc. Edinb. 1915, 50, 405-422. [CrossRef]

30. Rathke, H. Beiträge Zur Fauna Norwegens; Für die Akademie in Eduard Weber's Buchhandlng in Bonn: Bonn, Germany, 1843; Volume 1, pp. 1-264. 
31. Blake, J.A. The Scalibregmatidae (Annelida: Polychaeta) from South America and Antarctica collected chiefly during the cruises of the R/V Anton Bruun, R/V Hero and USNS Eltanin. Proc. Biol. Soc. Wash. 1981, 94, 1131-1162.

32. Pleijel, F.; Fauchald, K. Scalispinigera oculata Hartman, 1967 (Scalibregmatidae: Polychaeta): Senior synonym of Lacydonia antarctica (Lacydoniidae) Hartmann-Schröder \& Rosenfeldt, 1988. Proc. Biol. Soc. Wash. 1993, 106, 673-677.

33. Blake, J.A.; Maciolek, N.J. 7.6.2 Travisiidae Hartmann-Schröder, 1971, new family status. In Handbook of Zoology. Annelida: Pleistoannelida, Sedentaria II; Schmidt-Rhaesa, A., Ed.; De Gruyter: Berlin, Germany, 2020; pp. 302-311.

34. Mackie, Y. Scalibregma celticum new species (Polychaeta: Scalibregmatidae) from Europe, with a redescription of Scalibregma inflatum Rathke, 1843 and comments on the genus Sclerobregma Hartman, 1965. Bull. Mar. Sci. 1991, 48, 268-276.

35. Bakken, T.; Oug, E.; Kongsrud, J.A. Occurrence and distribution of Pseudoscalibregma and Scalibregma (Annelida, Scalibregmatidae) in the deep Nordic Seas, with the description of Scalibregma hanseni n. sp. Zootaxa 2013, 3753, 101-117. [CrossRef] [PubMed]

36. Blake, J.A. New species of Scalibregmatidae (Annelida, Polychaeta) from the East Antarctic Peninsula including a description of the ecology and post-larval development of species of Scalibregma and Oligobregma. Zootaxa 2015, 4033, 57-93. [CrossRef]

37. Schüller, M.; Hilbig, B. Three new species of the genus Oligobregma (Polychaeta, Scalibregmatidae) from the Scotia and Weddell Seas (Antarctica). Zootaxa 2007, 1391, 35-45. [CrossRef]

38. Kudenov, D.; Blake, J.A. A review of the genera and species of the Scalibregmidae (Polychaeta) with descriptions of one new genus and three new species from Australia. J. Nat. Hist. 1978, 12, 427-444. [CrossRef]

39. Nogueira, J.M.M. Asclerocheilus tropicus Blake, 1981 (Polychaeta: Scalibregmatidae): Redescription Based on Brazilian specimens. Proc. Biol. Soc. Wash. 2002, 115, 323-332.

40. Hartmann-Schröder, G. Zur Kenntnis des Sublitorals der Chilenischen Küste unter besonderer Berücksichtigung der Polychaeten und Ostracoden. II Die Polychaeten des Sublitorals. Mitt. Zool. Mus. Hamburg 1965, 62, 59-305.

41. Dehorne, A.; Dehorne, L. Recherches sur Sclerocheilus minutus (polychète de la famille des Scalibregmides). Morphologie, yeux, néphridie et pavillon. Arch. Zool. Exp. Gen. 1913, 53, 61-137.

42. Orrhage, L.; Müller, M. Morphology of the Nervous System of Polychaeta (Annelida). Hydrobiologia 2005, 535/536, 79-111. [CrossRef]

43. Martínez, A.; Di Domenico, M.; Worsaae, K. Gain of palps within a lineage of ancestrally burrowing annelids (Scalibregmatidae). Acta Zool. 2014, 95, 421-429. [CrossRef]

44. Fauchald, K.; Rouse, G. Polychaete systematics: Past and present. Zool. Scri. 1997, 26, 71-138. [CrossRef]

45. Spalding, M.D.; Fox, H.E.; Allen, G.R.; Davidson, N.; Ferdaña, Z.A.; Finlayson, M.; Halpern, B.S.; Jorge, M.A.; Lombana, A.; Lourie, S.A.; et al. Marine Ecoregions of the World: A Bioregionalization of Coastal and Shelf Areas. BioScience 2007, 57, 573-583. [CrossRef]

46. Paul, C.; Halanych, K.M.; Tiedemann, R.; Bleidorn, C. Molecules reject an opheliid affinity for Travisia (Annelida). Syst. Biodivers. 2010, 8, 507-512. [CrossRef]

47. Blake, J.A. Family Opheliidae Malmgren, 1867. In Taxonomic Atlas of the Benthic Fauna of the Santa Maria Basin and the Western Santa Barbara Channel. Vol. 7. The Annelida. Part 4: Polychaeta: Flabelligeridae to Sternaspidae; Blake, J.A., Hilbig, B., Scott, P.V., Eds.; Santa Barbara Museum of Natural History: Santa Barbara, CA, USA, 2000; Volume 7, pp. 145-168.

48. Bleidorn, C.; Vogt, L.; Bartolomaeus, T. New Insights into Polychaete Phylogeny (Annelida) Inferred from 18S RDNA Sequences. Mol. Phylogenet. Evol. 2003, 29, 279-288. [CrossRef]

49. Hall, K.A.; Hutchings, P.A.; Colgan, D.J. Further phylogenetic studies of the Polychaeta using 18S RDNA sequence data. J. Mar. Biol. Asspc. UK 2004, 84, 949-960. [CrossRef]

50. Belova, P.A.; Zhadan, A.E. Comparative morphology and ultrastructure of the respiratory system in four species of the Opheliidae family. Biol. Bull. 2014, 41, 752-772. [CrossRef]

51. Weigert, A.; Helm, C.; Meyer, M.; Nickel, B.; Arendt, D.; Hausdorf, B.; Santos, S.R.; Halanych, K.M.; Purschke, G.; Bleidorn, C.; et al. Illuminating the Base of the Annelid Tree Using Transcriptomics. Mol. Biol. Evol. 2014, 31, 1391-1401. [CrossRef]

52. Andrade, S.C.S.; Novo, M.; Kawauchi, G.Y.; Worsaae, K.; Pleijel, F.; Giribet, G.; Rouse, G.W. Articulating "Archiannelids": Phylogenomics and Annelid Relationships, with Emphasis on Meiofaunal Taxa. Mol. Biol. Evol. 2015, 32, 2860-2875. [CrossRef]

53. Sene-Silva, G. Filogenia de Opheliidae (Annelida: Polychaeta). Ph.D. Thesis, Universidade Federal do Paraná, Curitiba, Brazil, 2007.

54. Blake, J.A. Revalidation of the genus Thoracophelia Ehlers, 1897, replacing Euzonus Grube, 1866 (Polychaeta: Opheliidae), junior homonym of Euzonus Menge, 1854 (Arthropoda: Diplopoda), together with a literature summary and updated listing of Thoracophelia species. Zootaxa 2011, 2807, 65-68. [CrossRef]

55. Schüller, M. New Polychaete Species Collected during the Expeditions ANDEEP I, II, and III to the Deep Atlantic Sector of the Southern Ocean in the Austral Summers 2002 and 2005-Ampharetidae, Opheliidae, and Scalibregmatidae. Zootaxa 2008, 1705, 51-68. [CrossRef]

56. Day, J.H. A Monograph on the Polychaeta of Southern Africa. Part 2, Sedentaria; British Museum (Natural History): London, UK, 1967; Volume 2.

57. Santos, C.S.G.; Nonato, E.F.; Petersen, M.E. Two New Species of Opheliidae (Annelida: Polychaeta): Euzonus papillatus sp. n. from a Northeastern Brazilian Sandy Beach and Euzonus mammillatus sp. n. from the Continental Shelf of Southeastern Brazil. Zootaxa 2004, 478, 1-12. [CrossRef] 
58. Neave, M.J.; Glasby, C.J. New Species of Ophelina (Annelida: Opheliidae: Ophelininae) from Northern Australia. Org. Divers. Evol. 2013, 13, 331-347. [CrossRef]

59. Gopal, A.; Jaleel, A.K.U.; Parameswaran, U.V.; Vijayan, A.-K. Armandia sampadae, a new species of polychaete (Opheliidae) from Andaman Sea, Northern Indian Ocean. J. Mar. Biol. Assoc. UK 2016, 96, 1625-1632. [CrossRef]

60. Magalhães, W.F.; Rizzo, A.E.; Bailey-Brock, J.H. Opheliidae (Annelida: Polychaeta) from the Western Pacific Islands, including five new species. Zootaxa 2019, 4555, 209-235. [CrossRef]

61. Parapar, J.; Gambi, M.C.; Rouse, G.W. A revision of the deep-sea genus Axiokebuita Pocklington and Fournier, 1987 (Annelida: Scalibregmatidae). Ital. J. Zool. 2011, 78, 148-162. [CrossRef]

62. Parapar, J.; Moreira, J. Six new species of the genus Armandia Filippi, 1861 (Polychaeta, Opheliidae) from Lizard Island (Great Barrier Reef, Australia). Zootaxa 2015, 4019, 577-603. [CrossRef]

63. Moreira, J.; Parapar, J. New data on the Opheliidae (Annelida) from Lizard Island (Great Barrier Reef, Australia): Five new species of the genus Armandia Filippi, 1861. Zootaxa 2017, 4290, 483-502. [CrossRef]

64. Tzetlin, A.; Zhadan, A. Morphological variation of axial non-muscular proboscis types in the Polychaeta. Zoosymposia 2009, 2, 415-427. [CrossRef]

65. Purschke, G. Ultrastructure of Nuchal Organs in Polychaetes (Annelida)—New Results and Review. Acta Zool. 1997, 78, 123-143. [CrossRef]

66. Saito, H.; Tamaki, A.; Imajima, M. Description of a new species of Armandia (Polychaeta: Opheliidae) from Western Kyushu, Japan, with character variations. J. Nat. Hist. 2000, 34, 2029-2043. [CrossRef]

67. Bartolomaeus, T. Different photoreceptors in juvenile Ophelia rathkei (Annelida, Opheliida). Microfauna Mar. 1993, 8, 99-114.

68. Parapar, J.; Moreira, J. Sobre la presencia del género Ophelina Ørsted, 1843 (Polychaeta, Opheliidae) en el litoral de la península Ibérica. Nova Acta Cient. Compostel. Biol. 2008, 17, 117-134.

69. Hartmann-Schröder, G. Zur Morphologie der Opheliiden (Polychaeta Sedentaria). Z. Wiss. Zool. 1958, 161, 84-143.

70. Penry, D.L.; Jumars, P.A. Gut architecture, digestive constraints and feeding ecology of deposit-feeding and carnivorous polychaetes. Oecologia 1990, 82, 1-11. [CrossRef]

71. Bartolomaeus, T.; Quast, B. Structure and development of nephridia in Annelida and related taxa. Hydrobiologia 2005, 535, 139-165. [CrossRef]

72. West, D.L. Comparative Ultrastructure of juvenile and adult nuchal organs of an annelid (Polychaeta, Opheliidae). Tissue Cell 1978, 10, 243-257. [CrossRef]

73. Hermans, C.O. Fine structure of the segmental ocelli of Armandia brevis (Polychaeta: Opheliidae). Z. Zellforsch. Mikrosk. Anat. 1969, 96, 361-371. [CrossRef]

74. Parapar, J.; Candás, M.; Cunha-Veira, X.; Moreira, J. Exploring annelid anatomy using micro-computed tomography: A taxonomic approach. Zool. Anz. 2017, 270, 19-42. [CrossRef]

75. Bellan, G.; Dauvin, J.C. Phenetic and biogeographic relationships in Ophelia (Polychaeta, Opheliidae). Bull. Mar. Sci. 1991, 48, 544-558.

76. Neal, L.; Taboada, S.; Woodall, L.C. Slope-Shelf Faunal Link and Unreported Diversity off Nova Scotia: Evidence from Polychaete Data. Deep Sea Res. Part I Oceanogr. Res. Pap. 2018, 138, 72-84. [CrossRef]

77. Woodin, S.A. Polychaete Abundance Patterns in a Marine Soft-Sediment Environment: The Importance of Biological Interactions. Ecol. Monog. 1974, 44, 171-187. [CrossRef]

78. Kuş, S.; Kurt-Şahin, G. Temporal Changes in the Polychaeta (Annelida) Community Associated with Cystoseira Beds of Sinop Peninsula (Southern Black Sea). Turk. J. Fish. Aquat. Sci. 2016, 16, 61-68. [CrossRef]

79. Hadiyanto, H. Fouling Polychaetes in Tanjung Priok Port of Jakarta, Indonesia. ASEAN J. Sci. Technol. Dev. 2018, 35, 79-87. [CrossRef]

80. Dorgan, K.M.; Law, C.J.; Rouse, G.W. Meandering worms: Mechanics of undulatory burrowing in muds. Proc. R. Soc. B 2013, 280, 20122948. [CrossRef] [PubMed]

81. Dafoe, L.T.; Gingras, M.K.; Pemberton, S.G. Determining Euzonus mucronata Burrowing Rates with Application to Ancient Macaronichnus segregatis Trace-makers. Ichnos 2008, 15, 78-90. [CrossRef]

82. Riser, N.W. Observations on the genus Ophelia (Polychaeta: Opheliidae) with the description of a new species. Ophelia 1987, 28, 11-29. [CrossRef]

83. Castelli, A.; Lardicci, C.; Castellani, C.; Finocchiaro, C.; Genovesi, S.; Tataranni, M.; Maltagliati, F. Analysis of vertical distribution of two polychaetes (genus Ophelia) in sandy substrate along the Pisan Coast. Biol. Mar. Mediterr. 2006, 13, $160-161$.

84. Tamaki, A. Zonation by size in the Armandia sp. (Polychaeta: Opheliidae) population on an intertidal sand flat. Mar. Ecol. Prog. Ser. 1985, 27, 123-133. [CrossRef]

85. Fauchald, K.; Jumars, P.A. The diet of worms: A study of polychaete feeding guilds. Oceanogr. Mar. Biol. Ann. Rev. 1979, 17, 193-284.

86. Kemp, P.F. Direct uptake of detrital carbon by the deposit feeding polychaete Euzonus mucronata (Treadwell). J. Exp. Mar. Biol. Ecol. 1986, 99, 49-61. [CrossRef]

87. Guérin, J.-P. Modalités d'élevage et description des stades larvaires de Polyophthalmus pictus Dujardin (Annélide Polychète). Vie Milieu 1971, 22, 143-152. 
88. Giangrande, A. Polychaete reproductive patterns, life cycles and life histories: An overview. Oceanogr. Mar. Biol. Ann. Rev. 1997, $35,323-386$.

89. Hermans, C.O. Metamorphosis in the opheliid polychaete Armandia brevis. In Settlement and Metamorphosis of Marine Invertebrate Larvae; Chia, F., Rice, M.E., Eds.; Elsevier: New York, NY, USA, 1978; pp. 113-126.

90. Rivain, V. Contribution à L'étude Dynamique et Fonctionnelle des Peuplements de Sables fins du Golfe Normano-Breton. Ph.D Thesis, Université Pierre et Marie Curie, Paris, France, 1983.

91. Miner, B.G.; Sanford, E.; Strathmann, R.R.; Pernet, B.; Emlet, R.B. Functional and Evolutionary Implications of Opposed Bands, Big Mouths, and Extensive Oral Ciliation in Larval Opheliids and Echiurids (Annelida). Biol. Bull. 1999, 197, 14-25. [CrossRef]

92. Guérin, J.-P. Le développement larvaire d'Armandia cirrhosa Filippi (Annélide Polychète). Tethys 1972, 4, 969-974.

93. Parke, S.R. Biological Aspects of Speciation in Three Sympatric Euzonus Species at Dillon Beach, California (Polychaeta: Opheliidae). Master's Thesis, University of the Pacific, Stockton, CA, USA, 1973.

94. Wilson, D.P. The role of micro-organisms in the settlement of Ophelia bicornis Savigny. J. Mar. Biol. Assoc. UK 1955, 34, 531-543. [CrossRef]

95. Bely, A.E. Distribution of segment regeneration ability in the Annelida. Integr. Comp. Biol. 2006, 46, 508-518. [CrossRef]

96. Conradi, M.; Bandera, M.E.; Marin, I.; Martin, D. Polychaete-parasitizing copepods from the deep-sea Kuril-Kamchatka Trench (Pacific Ocean), with the description of a new Ophelicola species and comments on the currently known annelidicolous Copepods. Deep Sea Res. II 2015, 111, 147-165. [CrossRef]

97. Hartmann-Schröder, G. Annelida, Borstenwürmer, Polychaeta: Tierwelt Deutschlands 58 (Die Tierwelt Deutschlands und der Angrenzenden Meeresteile); Gustav Fischer: Jena, Germany, 1996; ISBN 978-3-437-35038-2.

98. Georgieva, Y.G.; Daskalov, G.M.; Klayn, S.L.; Stefanova, K.B.; Stefanova, E.S. Seasonal Diet and Feeding Strategy of Horse Mackerel Trachurus mediterraneus (Steindachner, 1868) (Perciformes: Carangidae) in the South-Western Black Sea. Acta Zool. Bulg. 2019, 71, 201-210.

99. Kicklighter, C.E.; Hay, M.E. Integrating Prey Defensive Traits: Contrasts of Marine Worms from Temperate and Tropical Habitats. Ecol. Monogr. 2006, 76, 195-215. [CrossRef]

100. Saes, R.V.S.T.; Moreira, L.B.; Davanso, M.B.; Perina, F.C.; Abess, D.M.S. Developing a protocol whole sediment toxicity testing with the polychaete Armandia agilis. Ecotoxicol. Environ. Contam. 2018, 13, 85-97. [CrossRef]

101. Malmgren, A.J. Annulata Polychaeta: Spetsbergiae, Groenlandiae, Islandiae et Scandinaviae. Hactenus Cognita; Ex Officina Frenckelliana: Helsinki, Finland, 1867.

102. Fauchald, K. Polychaetes from intertidal areas in Panama, with a review of previous shallow-water records. Smithson. Contr. Zool. 1977, 221, 1-81. [CrossRef]

103. Persson, J.; Pleijel, F. On the phylogenetic relationships of Axiokebuita, Travisia and Scalibregmatidae (Polychaeta). Zootaxa 2005, 998, 1-14. [CrossRef]

104. Helm, C.; Beckers, P.; Bartolomaeus, T.; Drukewitz, S.H.; Kourtesis, I.; Weigert, A.; Purschke, G.; Worsaae, K.; Struck, T.H.; Bleidorn, C. Convergent evolution of the ladder-like ventral nerve cord in Annelida. Front. Zool. 2018, 15, 36. [CrossRef]

105. Weigert, A.; Bleidorn, C. Current status of annelid phylogeny. Org. Divers. Evol. 2016, 16, 345-362. [CrossRef]

106. Örsted, A.S. Annulatorum Danicorum Conspectus. Fasc. I. Maricolæ; Librarie Wahliannae: Copenhagen, Denmark, 1843.

107. Grube, A.E. Beschreibung Neuer Oder Wenig Bekannter Anneliden. Sechster Beitrag. Arch. Nat. 1863, $29,37-69$.

108. Saint-Joseph, A.D. Les Annélides Polychètes Des Côtes de Dinard. Troisième Partie. Ann. Sci. Nat. 1849, 17, 1-395.

109. Hansen, G.A. Annelider Fra Den Norske Nordhavsexpedition i 1876. Nyt Mag. Naturvid. 1879, 24, 1-17.

110. McIntosh, W.C. On the Structure of the British Nemerteans, and Some New British Annelids. Trans. R. Soc. Edinb. 1869, 25, 305-433. [CrossRef]

111. Schmarda, L.K. Neue Wirbellose Thiere: Beobachted und Gesammelt auf einer Reise um die Erdr 1853 bis 1857. In Turbellarien, Rotatorien und Anneliden; Erster Band, Zweite Hälfte; Verlag von Wilhelm Engelmann: Leipzig, Germany, 1861.

112. McIntosh, W.C. Report on the Scientific Results of the Voyage of H.M.S. Challenger during the Years 1873-76, under the Command of Captain George S. Nares and the Late Captain Frank Tourle Thomson: A Summary of the Scientific Results; Printed for H.M.S.O.: London, UK, 1885.

113. Ehlers, E. Reports on the Results of Dredging, Under the Direction of L.F. Pourtalès, During the Years 1868-1870, and of Alexander Agassiz in the Gulf of Mexico (1877-78) and in the Caribbean Sea (1878-79), in the US Coast. Survey Steamer "Blake" Lieut.-Com. CD Sigsbee, USN, and Commander JR Bartlett, USN, Commanding. XXXI. Report on the Annelids. Mem. Mus. Comp. Zool. Harv. Coll. 1887, 15, 1-335.

114. Furreg, E. Zur Systematik Der Polychätenfamilie Scalibregmidae. Zool. Jahrb. Abt. Syst. Geogr. Biol. Tiere 1925, 50, 123-190.

115. Hartman, O. Deep-Water Benthic Polychaetous Annelids off New England to Bermuda and Other North Atlantic Areas. Allan Hancock Found. Publ. Occas. Pap. 1965, 28, 1-384.

116. Blake, J.A. Two new species of polychaetous annelid worms from Baffin Bay and the Davis Strait. Bull. South. Calif. Acad. Sci. 1972, 71, 127-132.

117. Day, J.H. The Polychaet [Sic] Fauna of South Africa. Part 6. Sedentary Species Dredged off Cape Coasts with a Few New Records from the Shore. J. Linn. Soc. 1961, 44, 463-560. [CrossRef]

118. Kirkegaard, J.B. Bathyal and Abyssal Polychaetes (Sedentary Species I). Galathea Rep. 1996, 17, 57-77. 
119. Blake, J. Family Scalibregmatidae Malmgren, 1867. In Taxonomic Atlas of the Benthic Fauna of the Santa Maria Basin and the Western Santa Barbara Channel. Vol. 7. The Annelida. Part 4: Polychaeta: Flabelligeridae to Sternaspidae; Blake, J., Hilbig, B., Scott, P., Eds.; Santa Barbara Museum of Natural History: Santa Barbara, CA, USA, 2000; Volume 4, pp. 129-144.

120. Imajima, M. Deep-Sea Benthic Polychaetes off Pacific Coast of the Northern Honshu, Japan. Natl. Mus. Nat. Sci. Monogr. 2009, 39, 39-192.

121. Imajima, M. Occurrence of Oncoscolex pacificus (Moore), a Species of Family Scalibregmidae (Polychaeta), in Japan. J. Hokkaido Gakugei Univ. 1961, 12, 11-13.

122. Støp-Bowitz, C. Les Scalibregmiens de Norvége. Medd. Zool. Mus. Oslo 1945, 55, 63-87.

123. Wesenberg-Lund, E. Lesser Antillean Polychaetes, Chiefly from Brackish Water with a Survey and a Bibliography of Fresh and Brackish-Water Polychaetes. Studies on the Fauna of Curaçao and Other Caribbean Islands 8.1. Stud. Fauna Curacao Caribb. Isl. 1958, 8, 1-41.

124. Bertelsen, R.D. Speleobregma lanzaroteum, a New Genus and Species of Scalibregmatidae (Polychaeta) from a Marine Cave in the Canary Islands. Proc. Biol. Soc. Wash. 1983, 99, 375-379.

125. Martínez, A.; Gonzalez, B.C.; Worsaae, K.; Wilkens, H.; Núñez, J.; Oromí, P.; Iliffe, T.M. Guide to the Anchialine Ecosystems of Jameos Del Agua and Túnel de La Atlántida; Medio Ambiente; Cabildo de Lanzarote: Arrecife, Spain, 2016. [CrossRef]

126. Martínez, A.; Palmero, A.M.; Brito, M.D.C.; Núñez, J.; Worsaae, K. Anchialine fauna of the Corona lava tube (Lanzarote, Canary Islands): Diversity, endemism and distribution. Mar. Biodiver. 2009, 39, 169-187. [CrossRef]

127. Martínez, A.; Gonzalez, B.C. Volcanic Anchialine Habitats of Lanzarote. In Cave Ecology. Ecological Studies (Analysis and Synthesis); Moldovan, O.T., Kovac, L., Halse, S., Eds.; Springer: Cham, Switzerland, 2019.

128. García-Valdecasas, A. Estudio Faunístico de La Cueva Submarina “Túnel de La Atlántida”, Jameos Del Agua, Lanzarote. Nat. Hisp. 1985, 27, 1-56.

129. Martínez, A.; Di Domenico, M.; Leasi, F.; Curini-Galletti, M.; Todaro, M.A.; Zotto, M.D.; Gobert, S.; Artois, T.; Norenburg, J.; Jörger, K.M.; et al. Patterns of Diversity and Endemism of Soft-Bodied Meiofauna in an Oceanic Island, Lanzarote, Canary Islands. Mar. Biodiv. 2019, 49, 2033-2055. [CrossRef]

130. Mammola, S.; Lunghi, E.; Bilandžija, H.; Cardoso, P.; Grimm, V.; Schmidt, S.I.; Hesselberg, T.; Martínez, A. Collecting EcoEvolutionary Data in the Dark: Impediments to Subterranean Research and How to Overcome Them. EcoEvorXiv 2020. [CrossRef]

131. Riera, R.; Monterroso, Ó.; Núñez, J.; Martínez, A. Distribution of meiofaunal abundances in a marine cave complex with secondary openings and freshwater filtrations. Mar. Biodivers. 2018, 48, 203-215. [CrossRef]

132. Gonzalez, B.C.; Martínez, A.; Borda, E.; Iliffe, T.M.; Fontaneto, D.; Worsaae, K. Genetic spatial structure of an anchialine cave annelid indicates connectivity within-but not between-islands of the Great Bahama Bank. Mol. Phylogenet. Evol. 2017, 109, 259-270. [CrossRef] [PubMed]

133. Dorgan, K.M.; Jumars, P.A.; Johnson, B.D.; Boudreau, B.P. Macrofaunal Burrowing: The Medium Is the Message. Oceanogr. Mar. Biol. Ann. Rev. 2006, 44, 5-121.

134. Elder, H.Y. Direct Peristaltic Progression and the Functional Significance of the Dermal Connective Tissues during Burrowing in the Polychaete Polyphysia crassa (Oersted). J. Exp. Biol. 1973, 58, 637-655.

135. Hunter, R.D.; Elder, H.L. Burrowing Dynamics and Energy Cost of Transport in the Soft-Bodied Marine Invertebrates Polyphysia crassa and Priapulus caudatus. J. Zool. 1983, 218, 209-222. [CrossRef]

136. Cahoon, L.B.; Laws, R.A.; Thomas, C.J. Viable diatoms and chlorophylla in continental slope sediments off Cape Hatteras, North Carolina. Deep Sea Res. Part II Top. Stud. Oceanogr. 1994, 41, 767-782. [CrossRef]

137. Aller, J.Y.; Aller, R.C.; Green, M.A. Benthic faunal assemblages and carbon supply along the continental shelf/shelf break-slope off Cape Hatteras, North Carolina. Deep Sea Res. Part II Top. Stud. Oceanogr. 2002, 49, 4599-4625. [CrossRef]

138. Blake, J.A.; Hilbig, B. Dense infaunal assemblages on the continental slope off Cape Hatteras, North Carolina. Deep Sea Res. Part II Top. Stud. Oceanogr. 1994, 41, 875-899. [CrossRef]

139. Worsaae, K.; Rouse, G.W. Mesonerilla neridae sp. nov. (Nerillidae): First meiofaunal annelid from deep-sea hydrothermal vents. Zoosymposia 2009, 2, 297-303. [CrossRef]

140. Hartman, O. Quantitative survey of the benthos of San Pedro Basin, southern California. Part II. Final results and conclusions. Allan Hancock Pac. Exped. 1966, 19, 187-455.

141. Hartmann-Schröder, G.; Hartmann, G. Zur Kenntnis Des Eulitorals Der Australischen Küsten Unter Besonderer Berücksichtigung Der Polychaeten Und Ostracoden (Extract Hyboscolex). Mitt. Hambg. Zool. Mus. Inst. 1979, 76, 75-218.

142. Hartman, O. Submarine canyons of southern California. Polychaetous Annelids. Allan Hancock Pac. Exped. 1963, $27,1-93$.

143. Wilkens, H.; Iliffe, T.M.; Oromí, P.; Martínez, A.; Tysall, T.N.; Koenemann, S. The Corona Lava Tube, Lanzarote: Geology, Habitat Diversity and Biogeography. Mar. Biodiv. 2009, 39, 155-167. [CrossRef]

144. Martínez, A.; Kvindebjerg, K.; Iliffe, T.M.; Worsaae, K. Evolution of cave suspension feeding in Protodrilidae (Annelida). Zool. Scr. 2017, 46, 214-226. [CrossRef]

145. Worsaae, K.; Gonzalez, B.C.; Kerbl, A.; Nielsen, S.H.; Jørgensen, J.T.; Armenteros, M.; Iliffe, T.M.; Martínez, A. Diversity and evolution of the stygobitic Speleonerilla nom. nov. (Nerillidae, Annelida) with description of three new species from anchialine caves in the Caribbean and Lanzarote. Mar. Biodiv. 2019, 49, 2167-2192. [CrossRef]

146. Ditlevsen, H. Annelids from the Danmark Expedition. Medd. Grønland Kobenhaven 1911, 45, 411-432.

147. Clark, R. Pelagic Swarming of Scalibregmidae (Polychaeta). Annu. Rep. Scott. Mar. Biol. Assoc. 1952, 53, $20-22$. 
148. Fage, L.; Legendre, R. Pêches Planctoniques à La Lumière, Effectuées à Banyuls-Sur-Mer et à Concarneau. I. Annélides Polychètes. Arch. Zool. Exp. Gen. 1927, 67, 23-222.

149. Blake, J.A. Life history analysis of five dominant infaunal polychaete species from the continental slope off North Carolina. J. Mar. Biol. Assoc. UK 1993, 73, 123-141. [CrossRef] 